Prepared in cooperation with the City of Durham Public Works Department, Stormwater and GIS Services Division

\title{
Groundwater/Surface-Water Interactions Along Ellerbe Creek in Durham, North Carolina, 2016-18
}

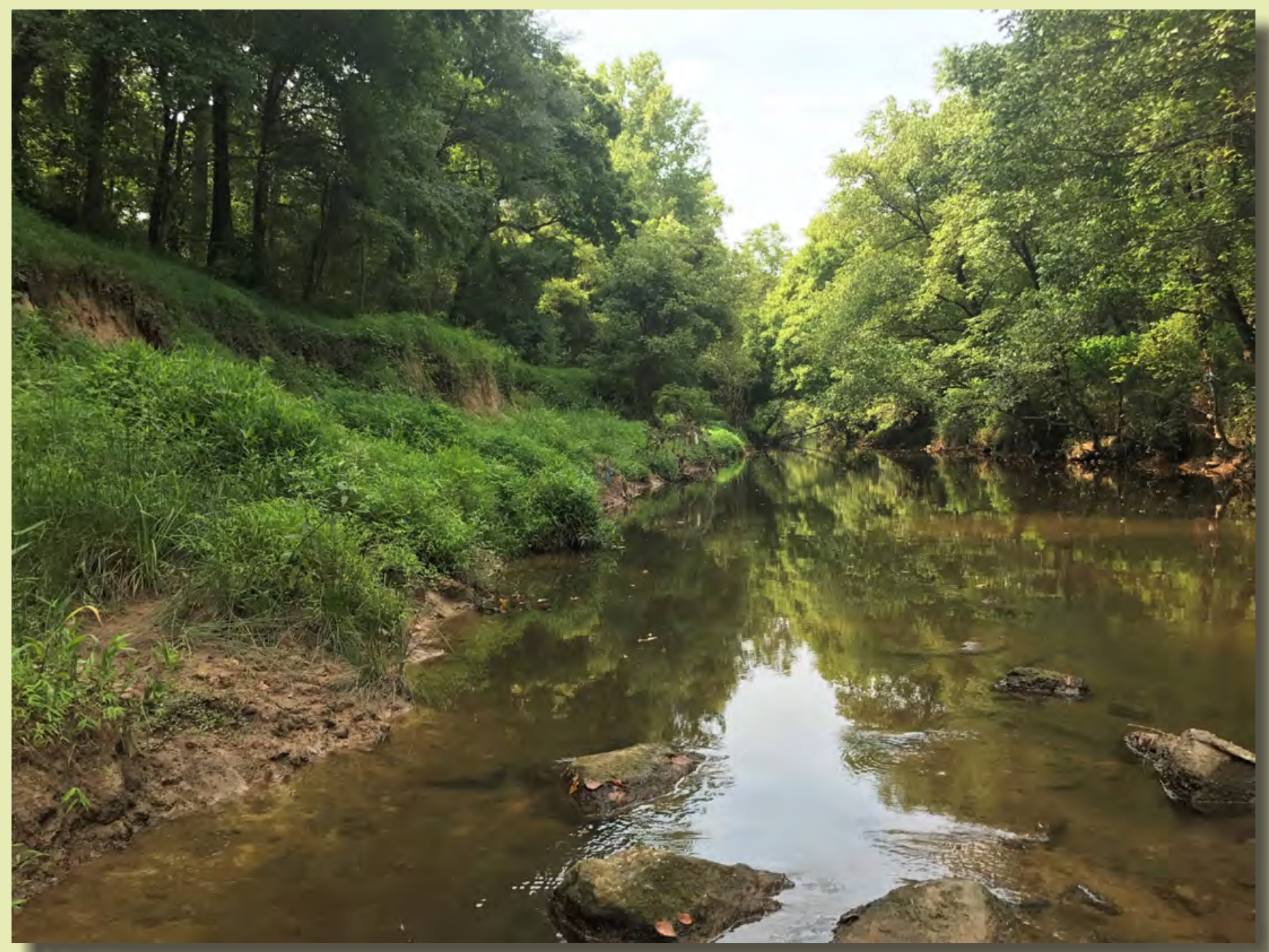

Scientific Investigations Report 2019-5097 
Cover. Ellerbe Creek in Durham, North Carolina, looking upstream from site EC-4. Photograph by Kristen McSwain, U.S. Geological Survey. 


\section{Ground water/Surface-Water Interactions Along Ellerbe Creek in Durham, North Carolina, 2016-18}

By Dominick J. Antolino

Prepared in cooperation with the City of Durham Public Works Department, Stormwater and GIS Services Division

Scientific Investigations Report 2019-5097 


\title{
U.S. Department of the Interior DAVID BERNHARDT, Secretary
}

\author{
U.S. Geological Survey \\ James F. Reilly II, Director
}

U.S. Geological Survey, Reston, Virginia: 2019

For more information on the USGS - the Federal source for science about the Earth, its natural and living resources, natural hazards, and the environment-visit https://www.usgs.gov or call 1-888-ASK-USGS.

For an overview of USGS information products, including maps, imagery, and publications, visit https://store.usgs.gov.

Any use of trade, firm, or product names is for descriptive purposes only and does not imply endorsement by the U.S. Government.

Although this information product, for the most part, is in the public domain, it also may contain copyrighted materials as noted in the text. Permission to reproduce copyrighted items must be secured from the copyright owner.

Suggested citation:

Antolino, D.J., 2019, Groundwater/surface-water interactions along Ellerbe Creek in Durham, North Carolina, 201618: U.S. Geological Survey Scientific Investigations Report 2019-5097, 32 p., https://doi.org/10.3133/sir20195097. 


\section{Acknowledgments}

The author thanks Michelle Woolfolk of the City of Durham Public Works Department, Stormwater and GIS Services Division, and John Dodson with the North Durham Water Reclamation Facility for their support and assistance with this project.

The author would also like to thank Kristen McSwain for her project guidance and other U.S. Geological Survey staff (Jeffrey Moss, Sharon Fitzgerald, Jessica Cain, Lee Bodkin, Jason Fine, Sean Egen, and Ryan Rasmussen) for their assistance with fieldwork and data analysis. 


\section{Contents}

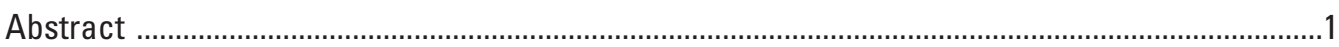

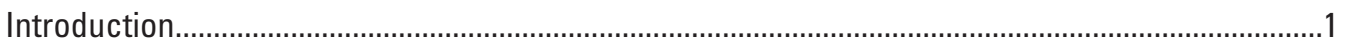

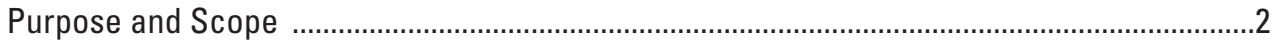

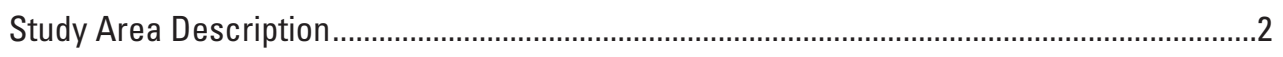

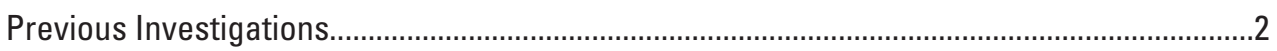

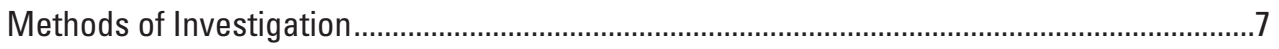

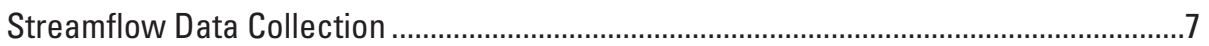

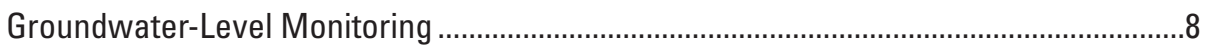

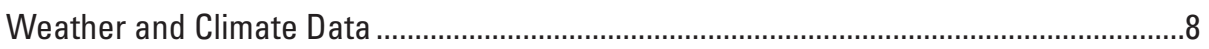

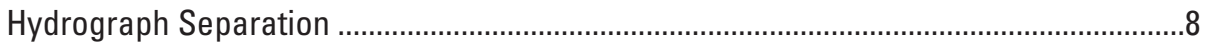

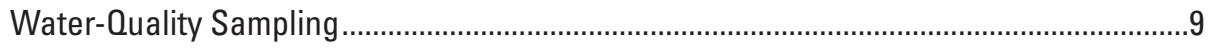

Water-Quality Control Samples ..............................................................................

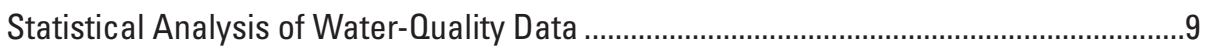

Water-Temperature Surveys ..............................................................................................

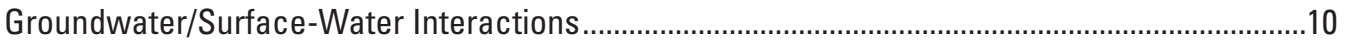

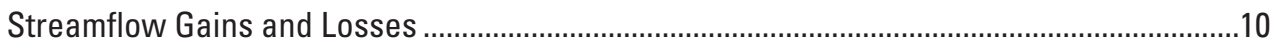

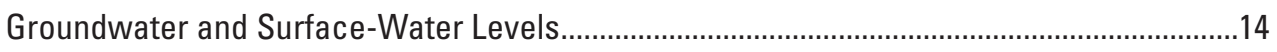

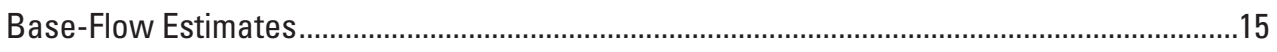

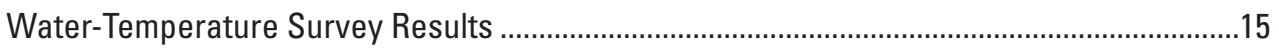

Reconnaissance of Bank Seeps Using Thermal Imaging ...........................................15

Distributed Temperature Sensing Results ................................................................17

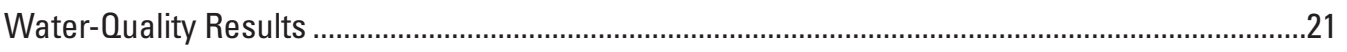

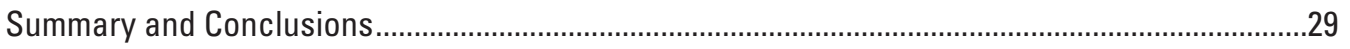

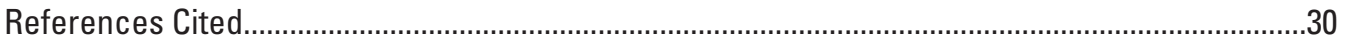

\section{Figures}

1. Map showing location of the study area in Durham, North Carolina, within the Piedmont physiographic province.

2. Map showing land cover within the Ellerbe Creek drainage area in Durham, North Carolina .

3. Map showing geology of the study area in Durham, North Carolina .................................5

4. Map showing location of surface-water, groundwater, and bank seep sites in the Ellerbe Creek study area in Durham, North Carolina.

5. Graphs showing discharge at U.S. Geological Survey streamgage 02086849, North Durham Water Reclamation Facility effluent discharge, and precipitation at the Climate Retrieval and Observations Network of the Southeast DURH site during a streamflow survey on July 12, 2016, and water-quality sampling on August 2, 2016; a fiber-optic distributed temperature sensing survey from July 18 to 25,2017 , and water-quality sampling on July 27,2017 ; and water-quality sampling from March 27 to 29, 2018, at Ellerbe Creek, Durham, North Carolina

6. Map showing stream reaches measured for a streamflow gain-loss survey on July 12, 2016, in Ellerbe Creek in Durham, North Carolina. 
7. Graphs showing continuous groundwater levels at sites PZ-1 and PZ-2 and surface-water level at site EC-4 and hydraulic gradients measured between December 1, 2017, and March 29, 2018, within Ellerbe Creek in Durham, North Carolina

8. Graphs showing base flow estimated by using the base-flow index and PART hydrograph separation methods for U.S. Geological Survey streamgage 02002086849 and streamgage 0208675010 in Ellerbe Creek in Durham, North Carolina

9. Example of a thermal image captured by the forward-looking infrared camera in March 2016 to determine stream surface and bank seep temperatures.

10. Distributed temperature sensing measurements collected from July 18 to 25 , 2017, in Ellerbe Creek, Durham, North Carolina.

11. Maps showing mean distributed temperature sensing measurements collected from July 18,2017 , to July 25,2017 , and stream depth measurements collected with an acoustic Doppler current profiler during base-flow conditions on July 27, 2017, at Ellerbe Creek in Durham, North Carolina .

12. Trilinear Piper diagram showing water-chemistry data for water-quality samples collected in July 2016 and March 2018 at surface-water sites, bank seeps, and groundwater wells in the Ellerbe Creek study area, Durham, North Carolina.

13. Boxplots showing range, median, and quartile statistical values for specific conductance, $\mathrm{pH}$, and nutrient concentrations of surface-water, groundwater, and bank seep samples collected in July and August 2016, July 2017, and March 2018 in the Ellerbe Creek study area in Durham, North Carolina

14. Map showing nitrate concentrations at surface-water and bank seep sites sampled in July and August 2016 in the Ellerbe Creek study area in Durham, North Carolina

15. Map showing nitrate concentrations at bank seep sites sampled in July 2017 in the Ellerbe Creek study area in Durham, North Carolina

16. Map showing nitrate concentrations at surface-water and groundwater sites sampled in March 2018 in the Ellerbe Creek study area in Durham, North Carolina ......28

\section{Tables}

1. Site information and map names for surface-water, bank seep, and groundwater sites in the Ellerbe Creek study area in Durham, North Carolina

2. Discrete water levels measured in November and December 2017 and March 2018 at groundwater and surface-water sites in the Ellerbe Creek study area in Durham, North Carolina

3. Measurements from the July 2016 gain-loss survey for reaches in Ellerbe Creek in Durham, North Carolina...

4. Summary of gain-loss determinations during the July 2016 gain-loss survey for reaches in Ellerbe Creek in Durham, North Carolina...

5. Temperature, specific conductance, dissolved oxygen, $\mathrm{pH}$, and nutrient concentrations of water-quality samples collected at Ellerbe Creek, Durham, North Carolina, from July 2016 to March 2018.

6. Major ion concentrations in water-quality samples collected at Ellerbe Creek, Durham, North Carolina, from July 2016 to March 2018 


\section{Conversion Factors}

U.S. customary units to International System of Units

\begin{tabular}{|c|c|c|}
\hline Multiply & By & To obtain \\
\hline \multicolumn{3}{|c|}{ Length } \\
\hline inch (in.) & 2.54 & centimeter $(\mathrm{cm})$ \\
\hline foot $(\mathrm{ft})$ & 0.3048 & meter $(\mathrm{m})$ \\
\hline mile (mi) & 1.609 & kilometer (km) \\
\hline \multicolumn{3}{|c|}{ Area } \\
\hline square mile $\left(\mathrm{mi}^{2}\right)$ & 2.590 & square kilometer $\left(\mathrm{km}^{2}\right)$ \\
\hline \multicolumn{3}{|c|}{ Flow rate } \\
\hline foot per second (ft/s) & 0.3048 & meter per second $(\mathrm{m} / \mathrm{s})$ \\
\hline foot per day (ft/d) & 0.3048 & meter per day $(\mathrm{m} / \mathrm{d})$ \\
\hline cubic foot per second $\left(\mathrm{ft}^{3} / \mathrm{s}\right)$ & 0.02832 & cubic meter per second $\left(\mathrm{m}^{3} / \mathrm{s}\right)$ \\
\hline million gallons per day (Mgal/d) & 0.04381 & cubic meter per second $\left(\mathrm{m}^{3} / \mathrm{s}\right)$ \\
\hline
\end{tabular}

International System of Units to U.S. customary units

\begin{tabular}{lcl}
\hline \multicolumn{1}{c}{ Multiply } & By & \multicolumn{1}{c}{ To obtain } \\
\hline \multicolumn{3}{c}{ Length } \\
\hline meter $(\mathrm{m})$ \\
kilometer $(\mathrm{km})$ & 3.281 & foot $(\mathrm{ft})$ \\
\hline
\end{tabular}

Temperature in degrees Celsius $\left({ }^{\circ} \mathrm{C}\right)$ may be converted to degrees Fahrenheit $\left({ }^{\circ} \mathrm{F}\right)$ as follows:

$$
{ }^{\circ} \mathrm{F}=\left(1.8 \times{ }^{\circ} \mathrm{C}\right)+32 .
$$

\section{Datum}

Vertical coordinate information is referenced to the North American Vertical Datum of 1988 (NAVD 88).

Horizontal coordinate information is referenced to the North American Datum of 1983 (NAD 83). Altitude, as used in this report, refers to distance above the vertical datum. 


\section{Supplemental Information}

Specific conductance is given in microsiemens per centimeter at 25 degrees Celsius $(\mu \mathrm{S} / \mathrm{cm}$ at $\left.25^{\circ} \mathrm{C}\right)$.

Concentrations of chemical constituents in water are given either in milligrams per liter (mg/L) or micrograms per liter $(\mu \mathrm{g} / \mathrm{L})$.

\section{Abbreviations}

$\begin{array}{ll}\text { ADCP } & \text { acoustic Doppler current profiler } \\ \text { ADV } & \text { acoustic Doppler velocimeter } \\ \text { BFI } & \text { base-flow index } \\ \text { CRONOS } & \text { Climate Retrieval and Observations Network of the Southeast } \\ \text { DGPS } & \text { differentially corrected Global Positioning System } \\ \text { DTS } & \text { distributed temperature sensing } \\ \text { FLIR } & \text { forward-looking infrared } \\ \text { FO-DTS } & \text { fiber-optic distributed temperature sensing } \\ \text { GUI } & \text { graphical user interface } \\ \text { lidar } & \text { light detection and ranging } \\ \text { NDWRF } & \text { North Durham Water Reclamation Facility } \\ \text { NLCD } & \text { National Land Cover Database } \\ \text { OA/OC } & \text { quality assurance and quality control } \\ \text { USGS } & \text { U.S. Geological Survey }\end{array}$




\title{
Groundwater/Surface-Water Interactions Along Ellerbe Creek in Durham, North Carolina, 2016-18
}

\author{
By Dominick J. Antolino
}

\section{Abstract}

An assessment of groundwater/surface-water interactions along Ellerbe Creek, a major tributary to upper Falls Lake in Durham County, North Carolina, was conducted from July 2016 to March 2018 to determine if groundwater is a likely source of elevated nitrate input to the stream. Groundwater/ surface-water interactions were characterized by synoptic streamflow measurements, groundwater-level monitoring, hydrograph-separation methods, and a continuous streambed temperature survey to aid in the collection and interpretation of water-quality data. A streamflow gain-loss survey identified gaining and losing reaches within the stream and found that surface-water inflow, including that from a treated wastewater outfall, provided much of the streamflow gain within the study reach. Through the use of two hydrograph-separation methods, base flow for the Ellerbe Creek study reach was estimated to be between 14.0 and 17.7 cubic feet per second during the study period, contributing up to 57 percent of mean streamflow, with the remaining contributions coming from surface runoff to the stream. The effluent discharge accounted for most of the estimated base-flow contribution to the stream below the North Durham Water Reclamation Facility outfall. Hydraulic gradients within the groundwater were determined to flow upward and toward the stream during base-flow conditions and reverse during storm events. Nitrate concentrations ranged from below the method detection level to 2.69 milligrams per liter, with the highest concentrations just downstream from the wastewater outfall. Bank seeps and groundwater samples had lower nitrate concentrations than surface-water samples, ranging from below the method detection level to 1.04 milligrams per liter, with the highest concentration at the piezometer within the stream. Results indicate that groundwater is not a large component of streamflow within Ellerbe Creek nor a major source of nitrate within the study reach.

\section{Introduction}

The North Carolina Department of Environmental Quality has included Falls Lake, a reservoir serving as the drinking water source for the city of Raleigh, North Carolina, and surrounding communities, on the 303(d) list of impaired waters because of violations of the State's chlorophyll $a$ waterquality standard that have been correlated to excessive nutrient inputs (North Carolina Department of Environment and Natural Resources, 2010). The nutrient management strategies adopted for the reservoir by the North Carolina Environmental Management Commission incorporate comprehensive controls to reduce nitrogen and phosphorus loads from primary sources in the watershed, including urban stormwater, wastewater, and agriculture (North Carolina Department of Environment and Natural Resources, 2010). Estimates of total nitrogen and phosphorus loads to Falls Lake from watershed model analysis show agriculture and point sources as the most important contributors to nitrogen and phosphorus levels within the reservoir (North Carolina Department of Environmental Quality, Division of Water Resources, 2016).

Ellerbe Creek, one of the major tributaries that discharges to upper Falls Lake, has a history of elevated nutrient concentrations that have been largely attributed to wastewater outfall from the North Durham Water Reclamation Facility (NDWRF; National Pollutant Discharge Elimination System permit number NC0023841), which is about 5 miles (mi) upstream from Falls Lake. Ongoing upgrades to and optimization of NDWRF water treatment processing are being implemented to reduce nutrient input to the reservoir. As part of the North Carolina Department of Environmental Quality Falls Lake Nutrient Strategy, Stage I mass limits for the three major wastewater dischargers in the upper watershed, including the NDWRF, were equivalent to an average of 3.09 milligrams per liter $(\mathrm{mg} / \mathrm{L})$ of total nitrogen for 110 percent of 2016 flows. The Ellerbe Creek drainage area is under the jurisdiction of the City of Durham, North Carolina. The city's Public Works Department, Stormwater and GIS Services Division, is tasked with assessing nutrient contributions to implement best management practices aimed at reducing nutrient loading in the Falls Lake drainage basin. Recent watershed modeling within the basin indicated that groundwater may be a possibly unquantified source of nutrient contributions to area streams (North Carolina Department of Environmental Quality, Division of Water Resources, 2016). 


\section{Purpose and Scope}

This report presents the results of a study to describe the interaction of groundwater and surface water in a reach of Ellerbe Creek downstream from the NDWRF. Streamflow measurements and groundwater-level monitoring were used to assess hydraulic gradients and estimate groundwater discharge to Ellerbe Creek. These monitoring data were coupled with temperature surveys and water-quality samples to assess whether groundwater may be a possible nonpoint source of nutrients to Ellerbe Creek and the Falls Lake watershed. This approach can improve understanding regarding the usefulness of the methods and techniques used in this study to characterize groundwater/surface-water interactions within Piedmont streams in Triassic sedimentary basins.

\section{Study Area Description}

The study area is in Durham County, North Carolina, within the Piedmont physiographic province. Ellerbe Creek is within the upper Neuse River Basin, upstream from Falls Lake (fig. 1), and is monitored for stage and streamflow by the U.S. Geological Survey (USGS) at streamgage 0208675010 (EC-1) and streamgage 02086849 (EC-11). The drainage area of Ellerbe Creek at EC-11, located at the downstream end of the study area, is 21.9 square miles $\left(\mathrm{mi}^{2}\right)$ and includes areas along Interstate 85 and north of downtown Durham. The land cover within the drainage area is predominantly urban (77 percent) with some forested coverage (15 percent) (fig. 2), according to the 2011 National Land Cover Database (NLCD) (Homer and others, 2015). The drainage area is underlain primarily by the sandstones and interbedded siltstones and mudstones of the Durham and Sanford subbasins of the Deep River Mesozoic basin (formerly known as the Triassic basin) (Brown and Parker, 1985; Hanna and Bradley, 2016) (fig. 3). Soils in the Ellerbe Creek drainage area are composed of unconsolidated, poorly sorted, and stratified sand, silt, and clay alluvium. The dominant hydrologic soil types for the study area are group C soils that have low infiltration rates, with more moderately drained group B soils farther upgradient from the stream. The U.S. Army Corps of Engineers straightened and channelized Ellerbe Creek in the early 1960s to control large volumes of surface runoff caused by the clayey, poorly draining soils and increased impervious surface area in the city of Durham (North Carolina Department of Environment and Natural Resources, 2003). Most of the Ellerbe Creek streambed is composed of alluvial sand and siltsized particles that mobilize readily under the rapidly changing high flows caused by surface runoff during storm events.

The groundwater system in the study area is composed of weathered regolith material at the land surface and underlying sedimentary bedrock that yields small quantities of water because of compaction and cementation within the rock (Chapman and others, 2013). Permeability of the aquifer may be slightly enhanced along lithologic contacts and bedding planes, as well as the openings and weathered areas around resistant diabase dikes within the study area that can provide preferential flow paths (fig. 3). The shallow regolith, which consists of soil residuum (clay), alluvium (older stream deposits), and saprolite (weathered bedrock material), is the shallowest portion of the groundwater system and serves as the primary storage reservoir for recharge to the deeper portions of the aquifer (Chapman and others, 2005).

The NDWRF, which is within the study reach, has a permitted capacity of 20 million gallons per day (Mgal/d) and discharges about $10 \mathrm{Mgal} / \mathrm{d}$ (15.5 cubic feet per second $\left[\mathrm{ft}^{3} / \mathrm{s}\right]$ ) of treated wastewater into Ellerbe Creek. A closed, unlined solid waste landfill that stopped receiving waste in 1997 is north of the NDWRF, approximately 1,000 feet (ft) east of Ellerbe Creek (fig. 4). A small, unnamed stream meanders along the southern and western edges of the landfill and discharges to Ellerbe Creek through a culvert located 1,800 ft downstream from the NDWRF outfall.

\section{Previous Investigations}

According to previous regional studies of shallow groundwater (Hallberg and Keeney,1993; Dubrovsky and others, 2010), the most widespread contaminant in groundwater from nonpoint anthropogenic sources is nitrogen. Messier and others (2014) developed a nonlinear landuse regression geostatistical model to predict point-level groundwater nitrate concentrations in North Carolina by using data from shallow groundwater monitoring wells and deeper private wells; median nitrate input values ranged from 0.10 to $1.30 \mathrm{mg} / \mathrm{L}$. Nitrate concentrations within the shallow monitoring wells varied widely, with wastewater treatment residuals and swine confined animal feeding operations as the dominant nitrate sources. McSwain and others (2014) assessed nitrate sources by using stable isotope compositions of nitrogen and oxygen at sites in three tributary creeks to Falls Lake, including USGS site 0208675010 on Ellerbe Creek, which is about 2.5 mi upstream from the NDWRF. Organic nitrogen accounted for more than 50 percent of the total measured nitrogen within the creeks, and nitrate plus nitrite concentrations were below $0.40 \mathrm{mg} / \mathrm{L}$ in all samples. Of the many potential sources of nitrate (for example, soil, atmospheric deposition, fertilizer, and manure and septic waste), the dominant source of nitrate to the three creeks was found to be the nitrification of soil nitrogen. Some storm samples also had atmospheric inputs of nitrate as a result of impervious-surface runoff directly entering streams. No evidence of septic or wastewater discharge was observed. 


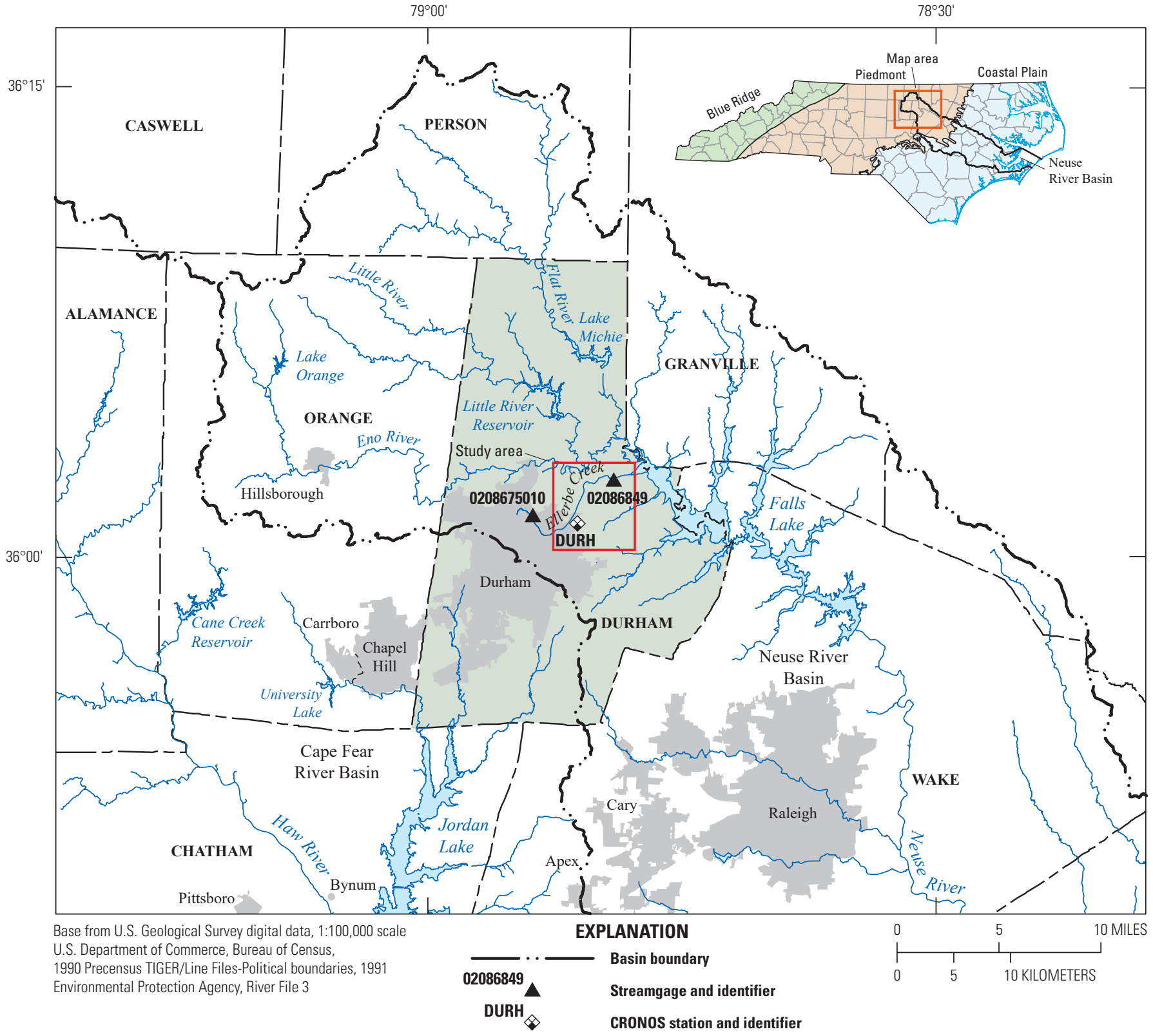

Figure 1. Map showing location of the study area in Durham, North Carolina, within the Piedmont physiographic province. Streamgage 0208675010 is site EC-1, and streamgage 02086849 is site EC-11. EC, Ellerbe Creek. 

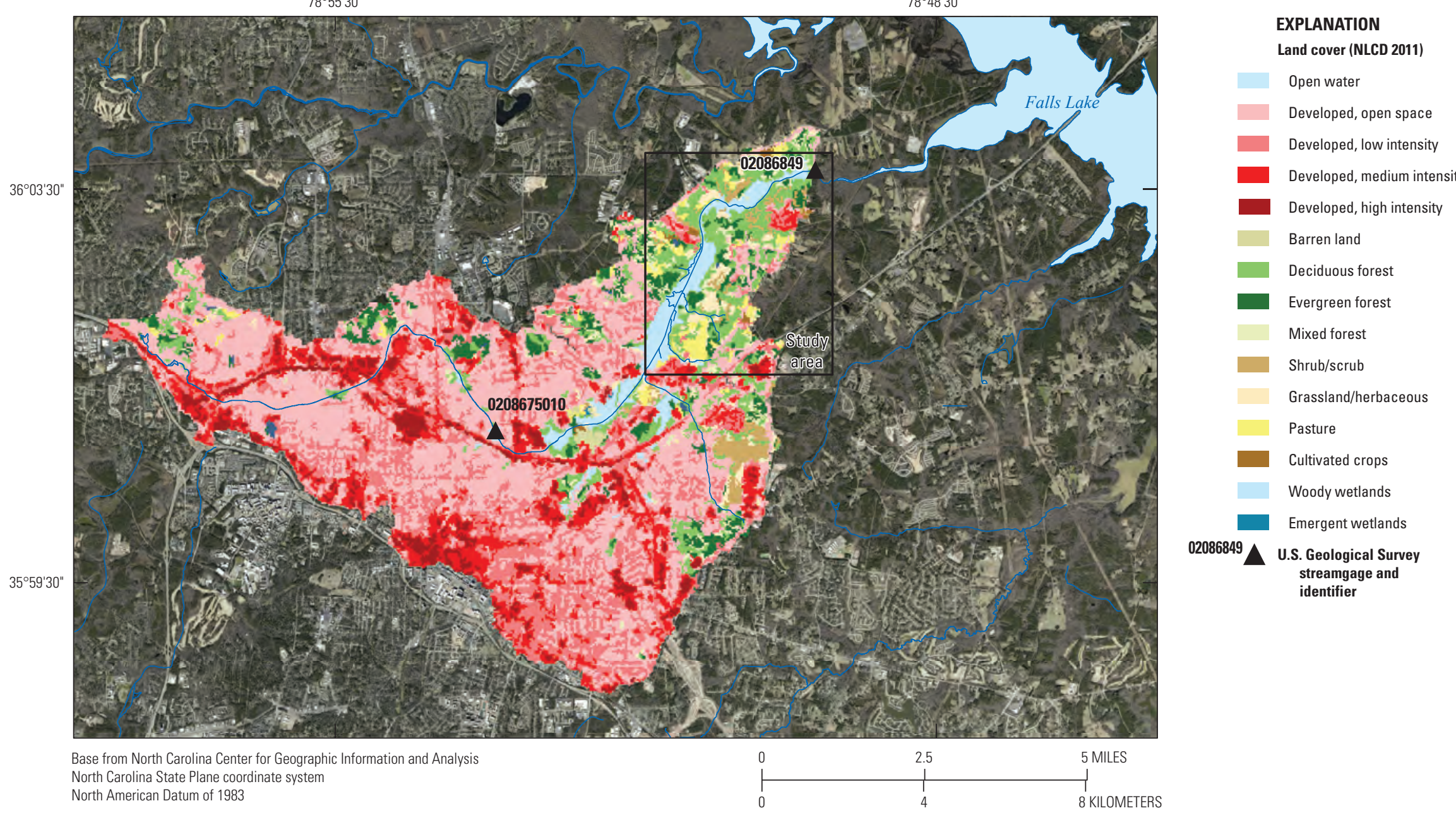

Figure 2. Map showing land cover within the Ellerbe Creek drainage area in Durham, North Carolina. Land-cover data are from the 2011 National Land Cover Database (NLCD 2011; Homer and others, 2015). Streamgage 0208675010 is site EC-1, and streamgage 02086849 is site EC-11. EC, Ellerbe Creek. 

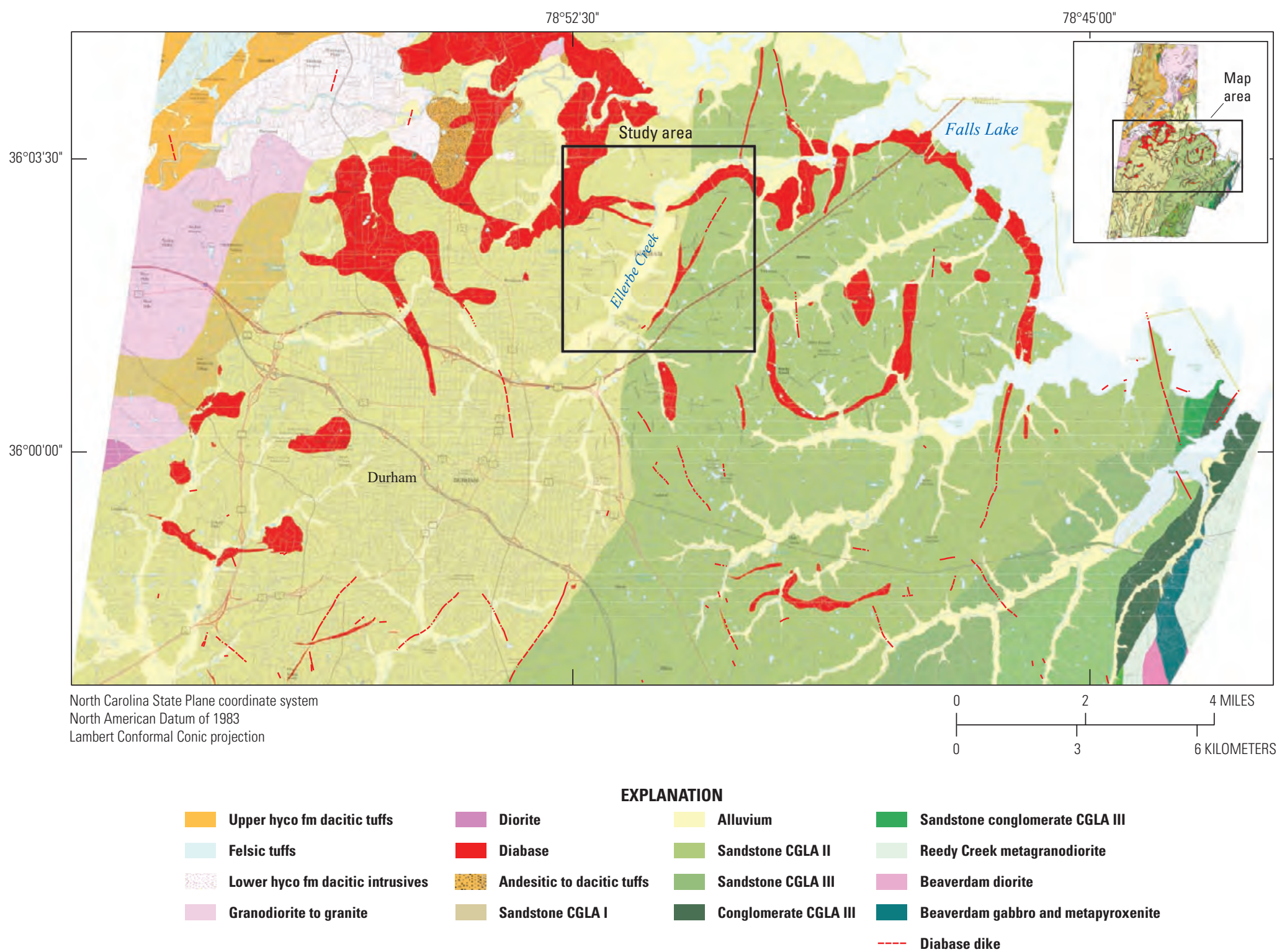

Figure 3. Map showing geology of the study area in Durham, North Carolina. The base map is modified from Hanna and Bradley (2016). Fm, formation; CGLA, Chatham Group Lithofacies Association. 


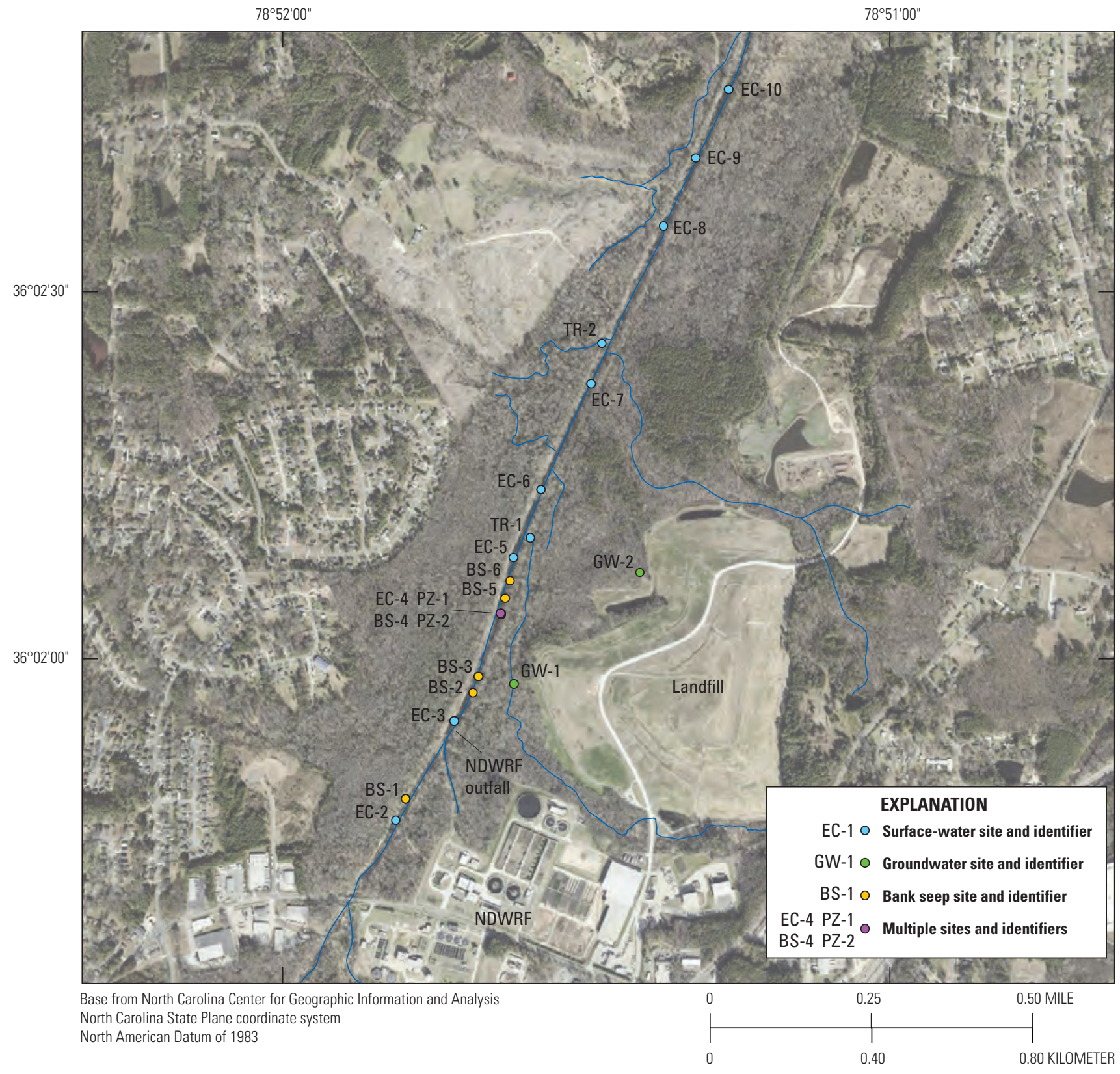

Figure 4. Map showing location of surface-water, groundwater, and bank seep sites in the Ellerbe Creek study area in Durham, North Carolina. Sites EC-1 and EC-11 are shown in figures 1 and 2. BS, bank seep; EC, Ellerbe Creek; GW, groundwater well; NDWRF, North Durham Water Reclamation Facility; PZ, piezometer. 


\section{Methods of Investigation}

This section provides a discussion of the methods used for describing the groundwater/surface-water interaction in Ellerbe Creek, including streamflow and groundwater data collection, water-quality sampling, and a distributed temperature survey. Map names for all study sites are used in place of USGS station names to make references concise within the text and figures (table 1).

\section{Streamflow Data Collection}

Streamflow data were collected at eight sites within Ellerbe Creek in July 2016 by using a handheld SonTek FlowTracker acoustic Doppler velocimeter (ADV) and a Teledyne RD Instruments StreamPro acoustic Doppler current profiler (ADCP) deployed from a tethered moving boat. The FlowTracker ADV instantaneous streamflow measurements were made by using the USGS midsection method (Young, 1950). The StreamPro ADCP allows threedimensional velocities to be measured from approximately $1.0 \mathrm{ft}$ beneath the water surface to within 6 percent of the depth to the bottom. The ADCP velocity, streamflow, and depth data were collected using standard USGS techniques (Mueller and others, 2013). Streamflow measurement locations were selected for gain-loss surveys to bracket tributary inflows and reaches suspected to contain shallow groundwater seeps. Hourly discharge data for the NDWRF effluent outfall from July 2014 to July 2018 were provided by the Durham Department of Water Management for reference (John Dodson, Durham Department of Water Management, written commun., 2018).

Table 1. Site information and map names for surface-water, bank seep, and groundwater sites in the Ellerbe Creek study area in Durham, North Carolina.

[NC, North Carolina; EC, Ellerbe Creek; Q, discharge; CR, Creek; RD, Road; NR, near; WQ, water quality; MI, mile; SR, Secondary Road; WL, water level; UT, unnamed tributary; BLW, below; TR, tributary; BL, below; BS, bank seep; MW, monitoring well; GW, groundwater well; PZBK, bank piezometer; PZ, piezometer; PZST, stream piezometer]

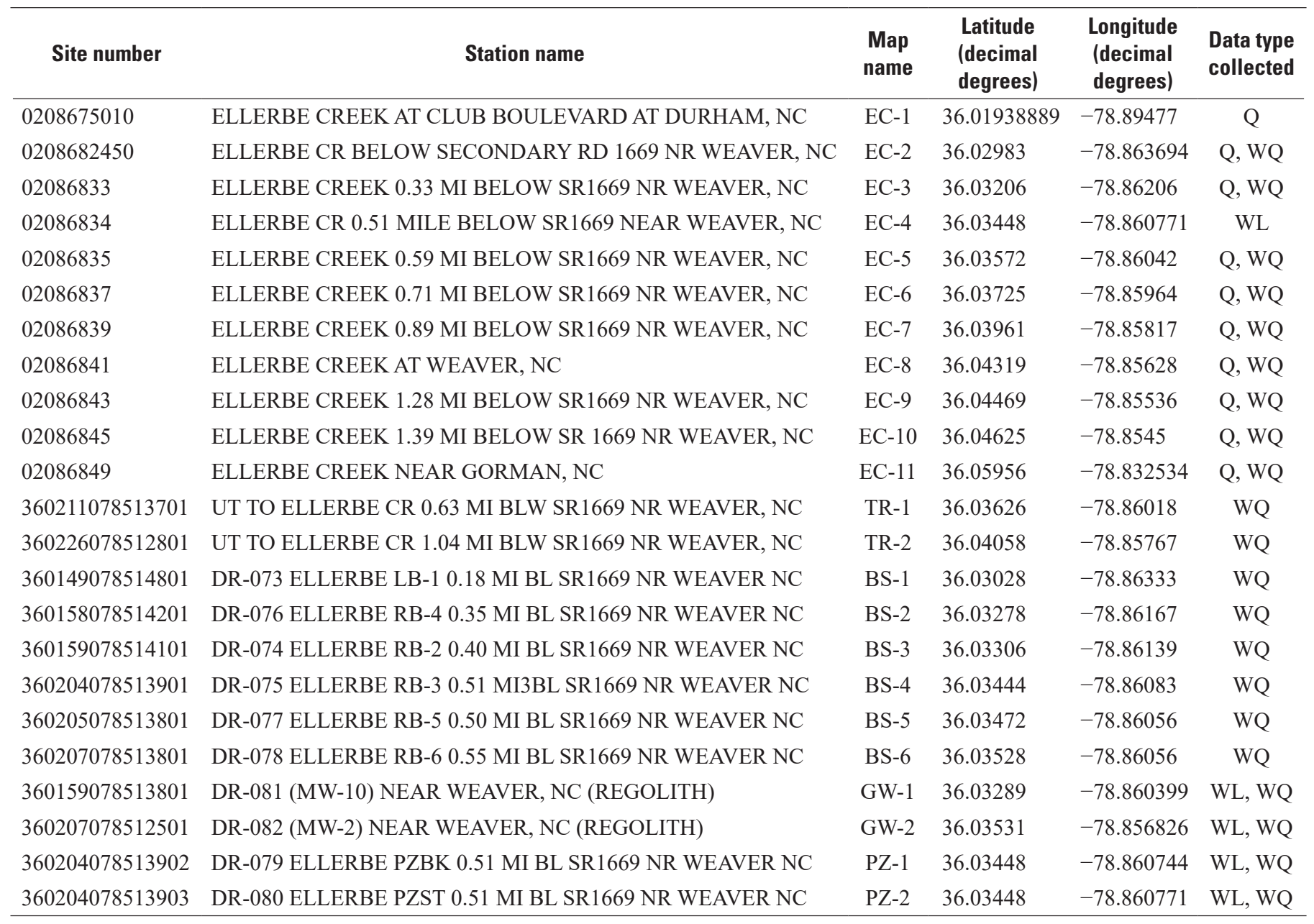




\section{Groundwater-Level Monitoring}

Groundwater-level measurements were collected at two piezometers (PZ-1 and PZ-2) and two monitoring wells (GW-1 and GW-2) in the study area to identify general flow direction and hydraulic gradients at the stream bank (table 2). The streambank piezometer (PZ-1) was installed to a depth of $3.4 \mathrm{ft}$ below land surface, and the stream piezometer (PZ-2) was installed to a depth of $5.5 \mathrm{ft}$ below the streambed. The lateral distance between the two piezometers was $10 \mathrm{ft}$. This section of the stream was selected for water-level monitoring due to the presence of and accessibility to a persistent bank seep (BS-4). The wells GW-1 and GW-2, part of a longterm monitoring network at the nearby unlined landfill, are about $600 \mathrm{ft}$ and 1,100 ft, respectively, from the piezometer sites (fig. 4).

Measurements were made from the top of the well casing with an electric water-level tape or a steel tape, using techniques described by Cunningham and Schalk (2011). The measuring points at PZ-1 and PZ-2 were surveyed in relation to a locally established bench mark to determine the altitude difference between the two sites. Land-surface altitudes at the locally established bench mark and two monitoring well sites were derived from 1-meter (m) high-density light detection and ranging (lidar) data (National Oceanic and Atmospheric Administration, 2015) with a mean vertical accuracy of $0.04 \mathrm{~m}$ and were reported in feet above the North American Vertical Datum of 1988 (NAVD 88). The distance from the land surface to the measuring point was then measured with an engineer's rule to determine the measuring point altitude. Continuous water levels were measured in piezometers at sites PZ-1 and PZ-2 from December 2017 to March 2018 by using internally logging unvented pressure transducers. Stream water level was measured at site EC-4 also using an internally logging unvented pressure transducer, which was secured to the downstream side of the piezometer at site PZ-2.
These datasets are available to the public through the USGS National Water Information System database (U.S. Geological Survey, 2018).

\section{Weather and Climate Data}

Hourly precipitation and air temperature data were collected by a North Carolina Climate Retrieval and Observations Network of the Southeast (CRONOS) station located at the NDWRF (CRONOS station DURH). A collaboration between State and Federal agencies, the CRONOS database contains weather and climate observations for 41 stations across 33 counties in North Carolina and is publicly available at https://climate.ncsu.edu/cronos.

\section{Hydrograph Separation}

Hydrograph-separation methods were used to estimate base flow within the 21.9- $\mathrm{mi}^{2}$ drainage area of site EC-11 (USGS streamgage 02086849), as well as within the 6.0-mi ${ }^{2}$ drainage area of the upstream site, EC-1 (USGS streamgage 0208675010), for comparison. Base flow is the component of streamflow largely sustained by groundwater discharge along the stream reach and is distinct from direct surface runoff. For the study area, base-flow estimates include natural base flows of steady groundwater discharge to Ellerbe Creek and its small tributary inflows, as well as anthropogenic inflows that have a relatively consistent discharge, such as effluent from the NDWRF. Hydrograph separation was done using the USGS Groundwater (GW) Toolbox, which is a software program that allows hydrograph analysis using six hydrograph-separation methods to calculate several components of the water budget, including base flow and surface-water runoff (Barlow and others, 2015). Two methods were used in the current study to determine lower and upper estimates of base flow; specifically, the base-flow index (BFI) and PART methods, respectively.

Table 2. Discrete water levels measured in November and December 2017 and March 2018 at groundwater and surface-water sites in the Ellerbe Creek study area in Durham, North Carolina.

[ft, foot; NADV 88, North American Vertical Datum of 1988; PZ, piezometer; GW, groundwater well; —, not measured; EC, Ellerbe Creek]

\begin{tabular}{llccccccccc}
\hline \multirow{2}{*}{ Site number } & $\begin{array}{c}\text { Map } \\
\text { name }\end{array}$ & $\begin{array}{c}\text { Land- } \\
\text { surface } \\
\text { altitude } \\
\text { (ft above } \\
\text { NAVD 88) }\end{array}$ & $\begin{array}{c}\text { Altitude } \\
\text { of top of } \\
\text { casing } \\
\text { (ft above } \\
\text { NAVD 88) }\end{array}$ & $\begin{array}{c}\text { Total } \\
\text { well } \\
\text { depth } \\
\text { (ft) }\end{array}$ & $\begin{array}{c}\text { Screened } \\
\text { interval } \\
\text { (ft) }\end{array}$ & $\begin{array}{c}\text { Casing } \\
\text { diameter } \\
\text { (inches) }\end{array}$ & $\begin{array}{c}\text { Water-level } \\
\text { altitude } \\
\text { (ft above } \\
\text { NAVD 88) } \\
\mathbf{1 1 / 2 9 / 1 7}\end{array}$ & $\begin{array}{c}\text { Water-level } \\
\text { altitude } \\
\text { (ft above } \\
\text { NAVD 88) } \\
\text { 12/1/17 }\end{array}$ & $\begin{array}{c}\text { Water-level } \\
\text { altitude } \\
\text { (ft above } \\
\text { NAVD 88) } \\
\text { 12/7/17 }\end{array}$ & $\begin{array}{c}\text { Water-level } \\
\text { altitude } \\
\text { (ft above } \\
\text { NAVD 88) }\end{array}$ \\
$\mathbf{3 / 2 9 / 1 8}$ \\
\hline 360204078513902 & PZ-1 & 271.2 & 271.80 & 3.4 & 1 & 1 & 269.19 & 269.52 & 270.46 & 270.39 \\
360204078513903 & PZ-2 & 268.0 & 269.53 & 5.5 & 1 & 1 & 269.03 & 269.13 & 269.28 & 269.38 \\
360159078513801 & GW-1 & 279.7 & 281.55 & 14.5 & 10 & 2 & - & - & - & 274.65 \\
360207078512501 & GW-2 & 283.8 & 285.52 & 18.0 & 10 & 2 & - & - & - & 281.91 \\
02086834 & EC-4 & 268.0 & 269.53 & - & - & - & 269.01 & 269.1 & 269.14 & 269.25 \\
\hline
\end{tabular}


The BFI method (Institute of Hydrology, 1980a, b; Wahl and Wahl, 1995) partitions the streamflow hydrograph into intervals of $N$ days to determine minimum flows within each interval. If 90 percent of the minimum of interest is less than adjacent minimums, then the flow is determined to be a "turning point" and is connected with other turning points to complete the base-flow hydrograph. The PART method (Rutledge, 1998) designates days that are unaffected by surface runoff as those that are preceded by $N$ days of continuous recession and linearly interpolates between these days to determine the base-flow hydrograph. For the current study, the period of analysis was October 1982 to January 2018 for USGS streamgage 02086849 (site EC-11) and July 2008 to January 2018 for streamgage 0208672010 (EC-1). The separation method parameters were set to a partition length of $N=5$ days, a turning point test factor of $F=0.90$, and a daily recession index of $K=0.97915$.

\section{Water-Quality Sampling}

Water-quality samples were collected at four groundwater sites, six bank seeps, and 11 surface-water sites in July and August 2016, July 2017, and March 2018. Sampling methods followed those outlined in the USGS "National Field Manual for the Collection of Water-Quality Data" (U.S. Geological Survey, 2006). Surface-water sampling was conducted at 10 sites in July 2016, concurrent with stream-discharge measurements. Three of these sites were again sampled in March 2018, along with downstream site EC-11, about $3 \mathrm{mi}$ downstream from the NDWRF. Water samples were collected at observable bank seeps using a drive-point piezometer connected to a peristaltic pump in August 2016 and in July 2017. The July 2017 sampling event coincided with the deployment of the fiber-optic distributed temperature sensing (FO-DTS) system described in the "Water-Temperature Surveys" section.

Groundwater, bank seep, and surface-water sites were sampled for nutrients, including nitrite, nitrate, and ammonia. Groundwater and surface-water sites were also sampled for major ions, iron, and manganese. All samples were analyzed at the USGS National Water Quality Laboratory in Denver, Colorado, using methods outlined in Fishman (1993).

\section{Water-Quality Control Samples}

Five field blanks and three sample replicates were also collected throughout the sampling process to address quality assurance and quality control (QA/QC). The blanks and replicates provide information regarding the accuracy and precision, respectively, of the water-quality data presented in this report. The QA/QC samples were collected in accordance with USGS policies and procedures documented in the National Field Manual (U.S. Geological Survey, 2006).

\section{Statistical Analysis of Water-Quality Data}

The water-quality data were summarized using Piper (trilinear) diagrams and box plots. Charge-balance errors calculated for the major cation and anion data of all samples were found to have less than a 10-percent difference, which was determined acceptable for statistical evaluation (U.S. Geological Survey, 1992). Piper diagrams are trilinear plots used to visually describe and compare the major ion composition of multiple samples of water on one graph. Ternary diagrams for both cations and anions are projected onto a diamond plot, where samples can be divided into hydrochemical facies or groups of samples with similar chemical characteristics as a result of similar hydrogeochemical processes (Piper, 1953). Using this approach, distinct source waters and the mixing relationships that exist between them can be identified, as well as any water-rock interactions that may occur along the groundwater flow path. Box plots also provide a way to visually compare datasets by displaying the statistical spread of the data (Sincich, 1993). The box encompasses the interval between the first and third quartiles (25th and 75th percentiles), with the median (50th percentile) represented by a horizontal line within the rectangular box. Lines and whiskers drawn from the first and third quartiles represent the values of the 10th and 90th percentiles of the dataset, respectively. For datasets that contained censored data for non-detection of a constituent (for example, nitrate), the rank method was used to determine summary statistics for the construction of boxplots. This method does not involve any assumption about the underlying distribution and is a simple and appropriate method for small datasets that have only one censoring value present (Bonn, 2008).

\section{Water-Temperature Surveys}

Temperature has been shown to be an effective tracer of groundwater movement near streams (Stonestrom and Constantz, 2003). The interaction of shallow groundwater with surface water can be assessed by contrasting the natural variations in stream water temperature resulting from seasonal and meteorological changes with the relatively stable groundwater temperatures. In a gaining stream reach during the summer, the relatively cooler thermal signature of discharging groundwater may be seen within the warmer surface water. The methods used for this study ensure measurement of distinct temperature differences, but these methods cannot be used to distinguish between no-flow and losing reaches. 
An initial reconnaissance survey in March 2016 and a subsequent survey in July 2016 were conducted to identify possible groundwater discharge points along the stream reach by using a forward-looking infrared (FLIR) camera in seasonal extremes. The high-resolution FLIR T620 and T640 thermal imaging cameras capture the emitted infrared radiation of the objects in view. Recent studies using similar ground-based thermal infrared imaging techniques have been successful in qualitatively locating groundwater discharge along discrete features, such as fractures and faults, as well as diffuse seepage along stream banks (Deitchman and Loheide, 2009; Pandey and others, 2013). Sites of interest were those where temperature differences were observed between the stream surface and points of streambank inflow, specifically where warmer groundwater was observed flowing from the streambank into the relatively cooler stream during the winter and where cooler groundwater was entering the relatively warmer stream during the summer.

FO-DTS can be used to determine differences in the temperature of surface water along a profile. With FO-DTS, surface-water temperatures are measured for several days along a fiber-optic cable that may extend more than a kilometer with a spatial resolution of less than $3 \mathrm{ft}$. Temperature precisions of 0.1 degree Celsius $\left({ }^{\circ} \mathrm{C}\right)$ and a temporal resolution of 90 seconds can be obtained (Selker and others, 2006). The measured temperature differences can often denote locations of groundwater discharge along a reach.

From July 18 to 25, 2017, an FO-DTS survey was completed by using a Sensornet ORYX distributed temperature sensing (DTS) system to delineate areas of groundwater discharge along Ellerbe Creek, just upstream from the NDWRF outfall to downstream from the closed municipal landfill. About $975 \mathrm{~m}$ of fiber-optic cable was deployed on the right bank (closest to the landfill) in the bed of the stream channel. Global Positioning System (GPS) location measurements were collected every $30 \mathrm{ft}$ along the cable during deployment, and a trolling SonTek RiverSurveyor M9 ADCP with a differentially corrected Global Positioning System (DGPS) receiver collected depth and location data every $1.6 \mathrm{ft}$ during cable retrieval to georeference the location of the cable. The DGPS received differential corrections from a Wide Area Augmentation System (WAAS) and is specified by the manufacturer to be accurate to $3.3 \mathrm{ft}$ at two standard deviations. Hourly air temperature was collected at the CRONOS DURH station located at the NDWRF.

Temperature data obtained by using the ORYX DTS system were collected between 18:39 on July 18, 2017, and $04: 26$ on July 25,2017 . Data were recorded every 15 minutes at intervals of about $3 \mathrm{ft}$ along the length of the fiber-optic cable. Ten consecutive temporal measurements made by the FO-DTS system over a 15-minute period were averaged to obtain 1 temperature measurement, for a total of 641 measurements collected over about 7 days. Analysis of the thermal data was done by using the DTS graphical user interface (GUI) program, currently under development by the USGS (Martin Briggs, U.S. Geological Survey, oral commun., 2018). The DTS GUI is a Python-based internal data visualization code that provides tools to import and view FO-DTS data in geospatial format.

\section{Groundwater/Surface-Water Interactions}

Groundwater/surface-water interactions were characterized by synoptic streamflow measurements, hydraulic gradients derived from water-level monitoring, and continuous streambed temperature using FO-DTS. The regolith aquifer is the principal hydrogeologic unit that interacts with surface-water features in the study area. Under typical conditions, when the water table follows the local topography, groundwater stored within the regolith aquifer would flow downgradient through the alluvium and discharge to the stream across miles of the entire stream reach. The discharge and recharge rates are dependent on the hydraulic gradient that exists between the groundwater system and the stream.

\section{Streamflow Gains and Losses}

To characterize the bulk exchange of water between the stream and surficial groundwater system, a streamflow gain-loss survey was conducted in Ellerbe Creek on July 12, 2016, at eight sites along the stream reach. According to data collected at USGS streamgage 02086849 (EC-11; location shown in figs. 1 and 2), the stream was under base-flow conditions during all discharge measurements. Streamflow ranged from 17.0 to 24.2 cubic feet per second $\left(\mathrm{ft}^{3} / \mathrm{s}\right)$, and stage ranged from 1.58 to $1.68 \mathrm{ft}$ above NAVD 88 before a rainfall event occurred post-survey, during the evening (fig. 5). According to data provided by the NDWRF, the effluent discharge ranged from 7.8 to $18.9 \mathrm{ft}^{3} / \mathrm{s}$ over the course of the survey. The survey covered about $1.4 \mathrm{mi}$ of Ellerbe Creek, starting at a site $740 \mathrm{ft}$ upstream from the NDWRF outfall (fig. 6). The remaining seven discharge sites were upstream and downstream from major inflows to the stream, including two culverts, multiple small creeks, and a nearby surfacewater impoundment.

The gain or loss in streamflow is estimated as the difference between inflow to the reach and outflow from the reach. A stream reach was classified as gaining or losing if the difference between the upstream and downstream discharge measurements exceeded the uncertainty error of both measurements. A meaningful streamflow gain within a reach was attributed to unmeasured tributary inflow and groundwater discharge to the stream. A meaningful seepage loss within a reach was assumed to be recharge to the groundwater system. Errors for each discharge measurement were based on measurement statistics generated by the ADV or ADCP data processing software. The total uncertainty in a discharge measurement includes uncertainty in cross-sectional area measurements, water-velocity profile measurements and assumptions, extrapolations for unmeasured areas, and random or systematic errors (Turnipseed and Sauer, 2010). 

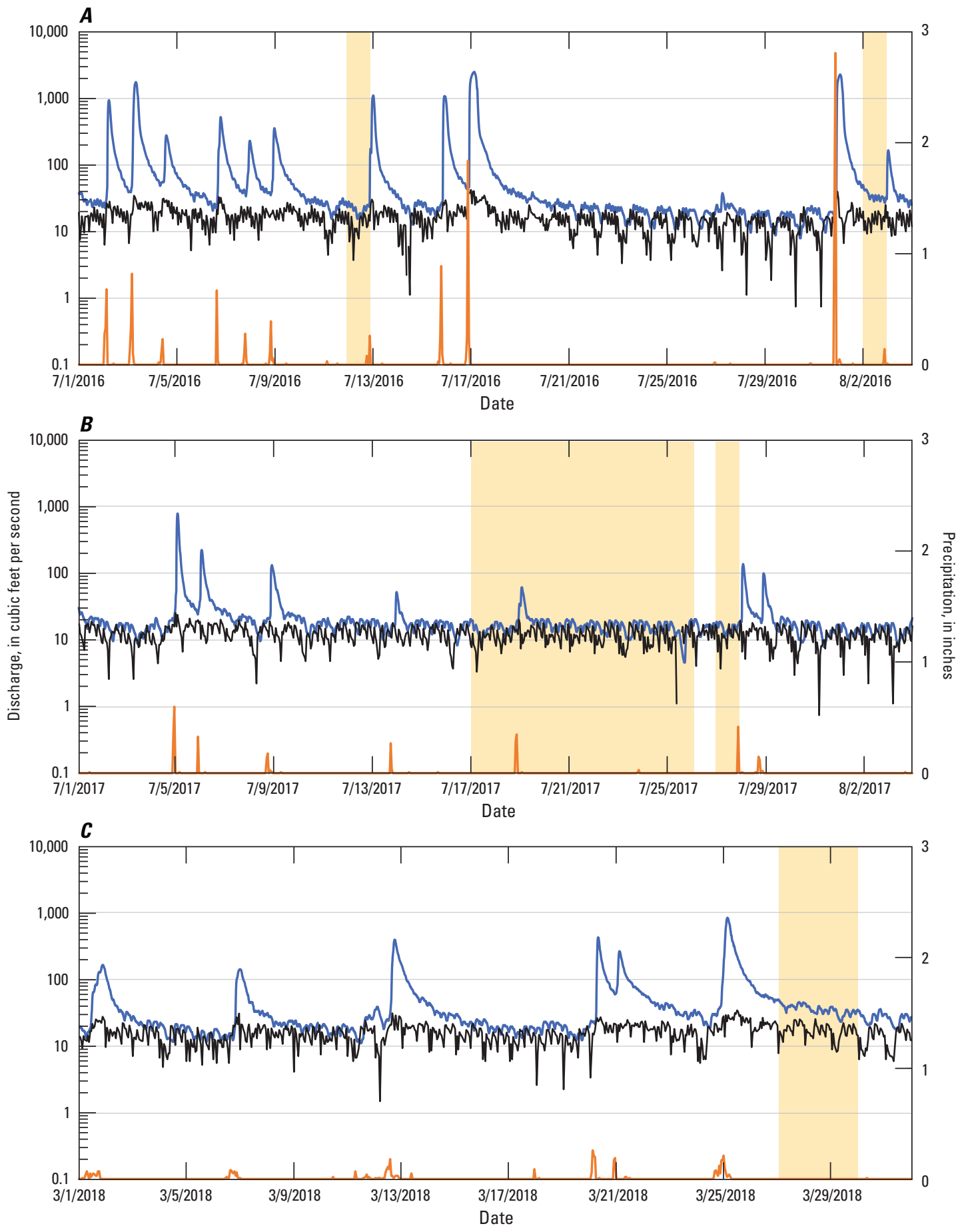

Figure 5. Graphs showing discharge at U.S. Geological Survey streamgage 02086849 (EC-11) (blue lines), North Durham Water Reclamation Facility effluent discharge (black lines), and precipitation at the Climate Retrieval and Observations Network of the Southeast DURH site (orange lines) during $(A)$ a streamflow survey on July 12, 2016, and water-quality sampling on August 2, 2016; $(B)$ a fiber-optic distributed temperature sensing survey from July 18 to 25, 2017, and water-quality sampling on July 27, 2017; and $(C)$ waterquality sampling from March 27 to 29, 2018, at Ellerbe Creek, Durham, North Carolina. Yellow highlights indicate measurements made during the given sampling and survey dates. 


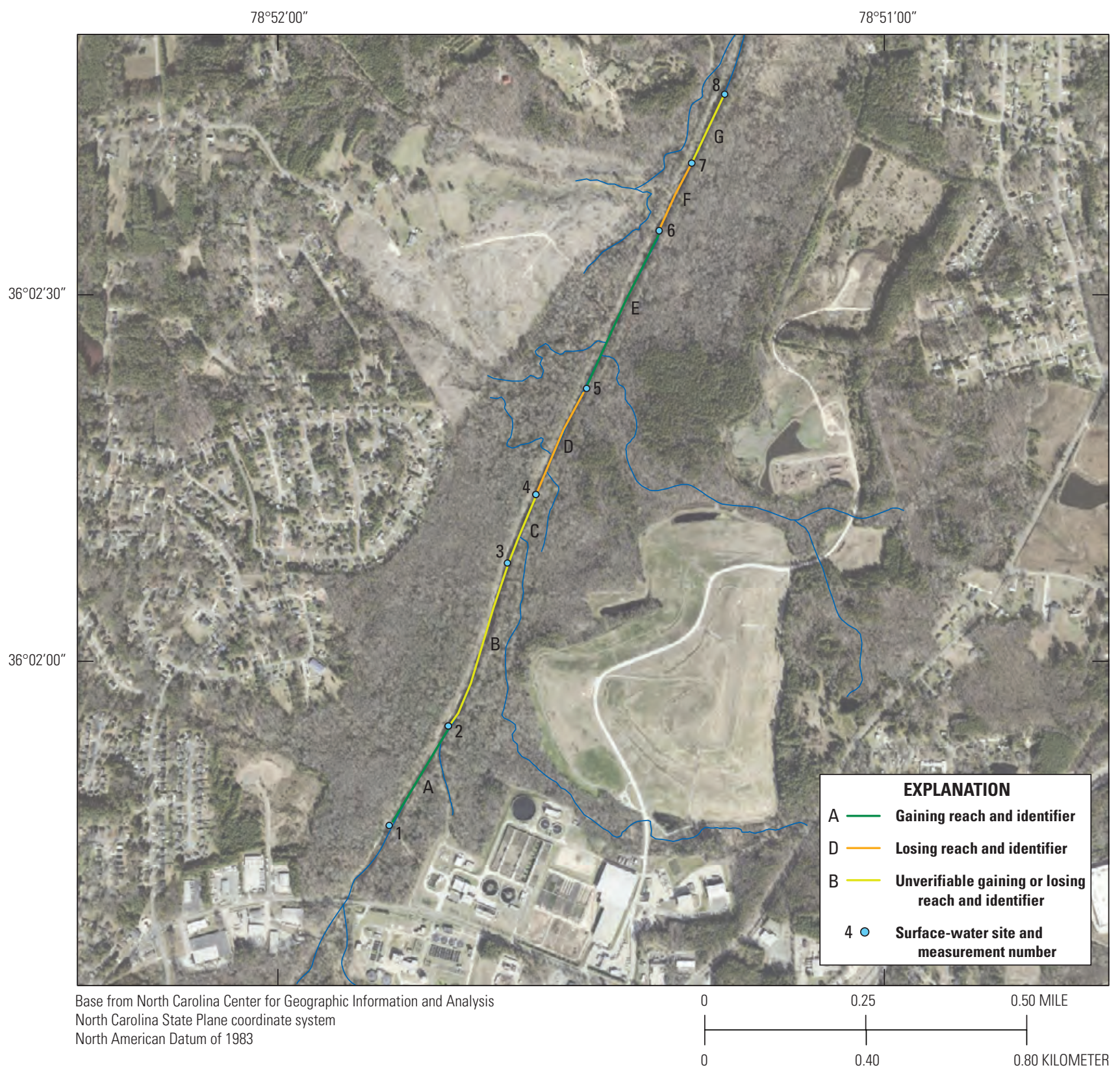

Figure 6. Map showing stream reaches measured for a streamflow gain-loss survey on July 12, 2016, in Ellerbe Creek in Durham, North Carolina.

All reaches evaluated for streamflow gains or losses in this stretch of Ellerbe Creek are depicted in figure 6 and summarized in tables 3 and 4 . Of the seven reaches assessed during the survey, reaches A and E had verifiable streamflow gain and reach $\mathrm{F}$ showed slight losing conditions. Reaches $\mathrm{B}$ and $\mathrm{G}$ did not have verifiable streamflow gain because the uncertainty errors exceed the inflow and outflow difference. Reach $\mathrm{C}$ had a relatively larger seepage loss, but upon consideration of the magnitude of uncertainty error coupled with an effluent discharge decrease of $2.4 \mathrm{ft}^{3} / \mathrm{s}$ between the inflow and outflow reach measurements, the observed loss is not meaningful. Flow from the tributary within reach $\mathrm{C}$ was not measured; however, the flow velocity was estimated to be between 1 and 2 feet per second through the 4 -ft culvert at a depth near $0.5 \mathrm{ft}$, and the inflow to the stream during the survey was estimated to be between 1 and $2 \mathrm{ft}^{3} / \mathrm{s}$. 
Table 3. Measurements from the July 2016 gain-loss survey for reaches in Ellerbe Creek in Durham, North Carolina.

[ft/s, foot per second; $\mathrm{ft}^{3} / \mathrm{s}$, cubic foot per second; NDWRF, North Durham Water Reclamation Facility; ADV, acoustic Doppler velocimeter; - , not measured; ADCP, acoustic Doppler current profiler]

\begin{tabular}{|c|c|c|c|c|c|c|c|c|c|}
\hline Site number & $\begin{array}{c}\text { Measure- } \\
\text { ment } \\
\text { number }\end{array}$ & Method & Date and time & $\begin{array}{l}\text { Mean } \\
\text { velocity, } \\
\text { ft/s }\end{array}$ & $\begin{array}{c}\text { Discharge, } \\
\mathrm{ft}^{3} / \mathrm{s}\end{array}$ & $\begin{array}{l}\text { Uncertainty, } \\
\text { percent }\end{array}$ & $\begin{array}{l}\text { Uncertainty, } \\
\mathrm{ft}^{3} / \mathrm{s}(+/-)\end{array}$ & $\begin{array}{c}\text { Change } \\
\text { in NDWRF } \\
\text { discharge } \\
\text { during } \\
\text { measurement, } \\
\mathrm{ft}^{3} / \mathrm{s}\end{array}$ & $\begin{array}{c}\text { Change } \\
\text { in NDWRF } \\
\text { discharge } \\
\text { from upstream } \\
\text { measurement, } \\
\text { ft }{ }^{3} / \mathrm{s}\end{array}$ \\
\hline 0208682450 & 1 & $\mathrm{ADV}$ & 7/12/2016 10:31 & 0.34 & 5.5 & 2.7 & 0.1 & - & - \\
\hline 02086833 & 2 & ADCP & $7 / 12 / 201612: 25$ & 0.40 & 26.3 & 5.3 & 1.4 & -0.3 & - \\
\hline 02086835 & 3 & $\mathrm{ADCP}$ & 7/12/2016 13:06 & 0.41 & 26.9 & 23.0 & 6.2 & -0.6 & 0.0 \\
\hline 02086837 & 4 & $\mathrm{ADV}$ & 7/12/2016 14:12 & 0.56 & 19.7 & 2.5 & 0.5 & -1.9 & -2.4 \\
\hline 02086839 & 5 & $\mathrm{ADV}$ & $7 / 12 / 201614: 53$ & 0.63 & 18.0 & 3.2 & 0.6 & -1.9 & 0.0 \\
\hline 02086841 & 6 & $\mathrm{ADV}$ & 7/12/2016 16:37 & 0.46 & 25.6 & 4.0 & 1.0 & 1.7 & 1.5 \\
\hline 02086843 & 7 & ADV & 7/12/2016 15:37 & 0.27 & 21.1 & 3.1 & 0.7 & -0.9 & 0.4 \\
\hline 02086845 & 8 & $\mathrm{ADV}$ & $7 / 12 / 201616: 08$ & 0.26 & 21.2 & 4.9 & 1.0 & -0.9 & 0.0 \\
\hline
\end{tabular}

Table 4. Summary of gain-loss determinations during the July 2016 gain-loss survey for reaches in Ellerbe Creek in Durham, North Carolina.

$\left[\mathrm{ft}^{3} / \mathrm{s}\right.$, cubic foot per second; $\mathrm{ft}$, foot; $\mathrm{ft} / \mathrm{s}$, foot per second]

\begin{tabular}{ccccccc}
\hline Reach name & $\begin{array}{c}\text { Associated } \\
\text { measurements }\end{array}$ & $\begin{array}{c}\text { Gain or loss, } \\
\mathbf{f t}^{3} \mathbf{s}\end{array}$ & $\begin{array}{c}\text { Total uncertainty, } \\
\mathbf{f t}^{3} / \mathbf{s}(\mathbf{+} / \mathbf{-}\end{array}$ & $\begin{array}{c}\text { Reach distance, } \\
\mathbf{f t}\end{array}$ & $\begin{array}{c}\text { Averaged velocity, } \\
\mathbf{f t / s}\end{array}$ & $\begin{array}{c}\text { Travel time, } \\
\text { minutes }\end{array}$ \\
\hline $\mathrm{A}$ & 1,2 & 20.8 & 1.5 & 965 & 0.37 & 43.5 \\
$\mathrm{~B}$ & 2,3 & 0.6 & 7.6 & 815 & 0.41 & 33.5 \\
$\mathrm{C}$ & 3,4 & -7.18 & 6.7 & 605 & 0.49 & 20.8 \\
$\mathrm{D}$ & 4,5 & -1.768 & 1.1 & 965 & 0.60 & 27.0 \\
$\mathrm{E}$ & 5,6 & 7.6 & 1.6 & 1,380 & 0.55 & 42.2 \\
F & 6,7 & -4.514 & 1.7 & 610 & 0.37 & 27.9 \\
G & 7,8 & 0.1 & 1.7 & 620 & 0.27 & 39.0 \\
\hline
\end{tabular}

Reach A contains the NDWRF outfall, which likely accounts for much of the measured gain for the reach. A streamflow gain of $7.6 \mathrm{ft}^{3} / \mathrm{s}$ in reach E was attributed to both groundwater discharge and the two small, unmeasured tributaries flowing into the stream within the reach. A seepage loss of $1.8 \mathrm{ft}^{3} / \mathrm{s}$ measured in reach $\mathrm{D}$ indicates the combined contributions of groundwater discharge within the reach, and inflow from a small unmeasured tributary was exceeded by seepage loss to the groundwater system. Reach $\mathrm{F}$ also showed a meaningful seepage loss to the groundwater system of $4.5 \mathrm{ft}^{3} / \mathrm{s}$.

Calculations from the streamflow gain-loss survey showed that Ellerbe Creek has both gaining and losing reaches within the study area. Only reaches A and E had verifiable streamflow gain $\left(20.8 \mathrm{ft}^{3} / \mathrm{s}\right.$ and $7.6 \mathrm{ft}^{3} / \mathrm{s}$, respectively), which cannot be attributed solely to groundwater because small tributaries flow into the stream within both reaches, as well as NDWRF effluent inflow within reach A. Reach D showed a small but verifiable seepage loss despite containing two tributary inflows. Though the discharge from the NDWRF outfall fluctuated throughout the survey, the observed seepage losses were not related to decreases in effluent flow to the stream. Both inflow and outflow measurements in reach D were completed under stable effluent discharge conditions, whereas the volume of effluent discharge increased by $0.4 \mathrm{ft}^{3} / \mathrm{s}$ between the inflow and outflow measurements for reach $\mathrm{F}$, which would slightly reduce the observed seepage loss (table 2). Diabase dikes cut across the bedrock underlying the alluvial sediments in this area of Ellerbe Creek (fig. 3), particularly within reach F (fig. 6). Though diabase dikes are not permeable and may act as an impermeable boundary to groundwater discharge (McSwain and others, 2009), preferential pathways along the weathered contact areas may divert groundwater along the dike. Weaver and McSwain (2013) observed no-flow or losing stream conditions in the Cape Fear River near Raven Rock State Park in North Carolina that coincided with the presence of diabase dikes intersecting the reach. 


\section{Groundwater and Surface-Water Levels}

Continuous groundwater levels within two piezometers (PZ-1 and PZ-2) were recorded concurrently with continuous stream-level readings at site EC-4 between December 1, 2017, and March 28, 2018, to calculate hydraulic gradients in Ellerbe Creek during the wet season (fig. 7). Surface-water levels ranged from 268.65 to $273.54 \mathrm{ft}$ above NAVD 88, and groundwater levels ranged from 268.71 to $273.20 \mathrm{ft}$ above NAVD 88. Groundwater levels typically were higher than surface-water levels across the monitoring period, except during storm events when stream levels rose above groundwater levels. The hydrographs for both surface water and groundwater show similar patterns, likely because of hydrostatic pressure from the stream having direct communication to the shallow groundwater system through the alluvial sediments.
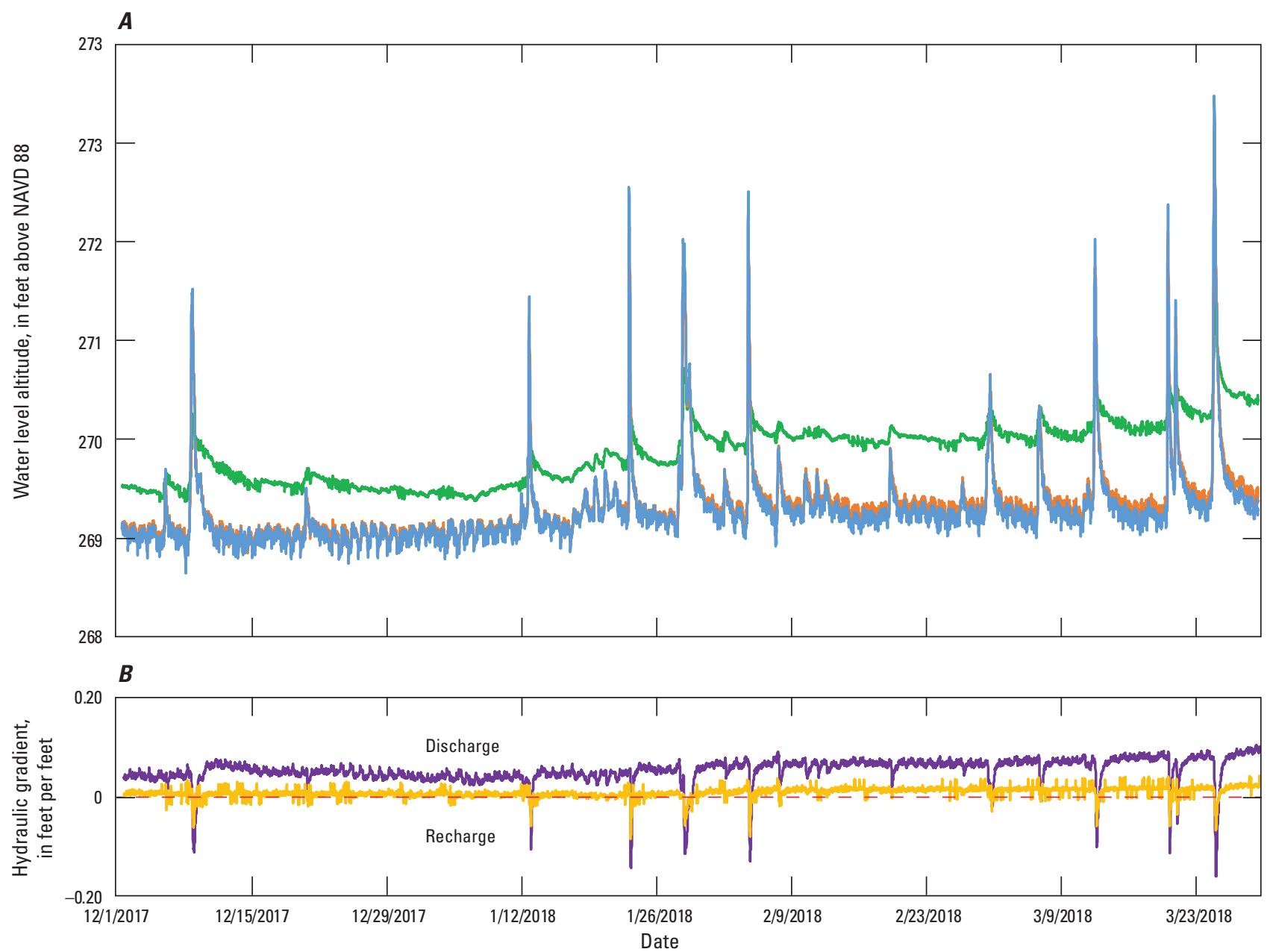

EXPLANATION

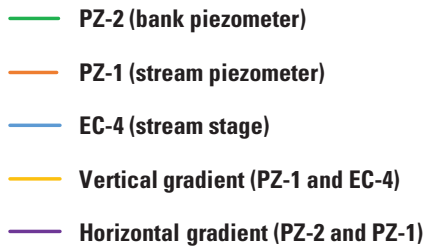

Figure 7. Graphs showing $(A)$ continuous groundwater levels at sites PZ-1 and PZ-2 and surface-water level at site EC-4 and $(B)$ hydraulic gradients measured between December 1, 2017, and March 29, 2018, within Ellerbe Creek in Durham, North Carolina. EC, Ellerbe Creek; NAVD 88, North American Vertical Datum of 1988; PZ, piezometer. 
Positive vertical gradients indicate upward flow of groundwater discharge to the stream and negative gradients indicate downward flow, or groundwater recharge. Vertical gradients between the groundwater system beneath the stream and the stream level ranged from -0.08 to 0.04 foot per foot $(\mathrm{ft} / \mathrm{ft})$, with the mean near $0.01 \mathrm{ft} / \mathrm{ft}$. The higher negative gradients coincided with storm events and had a duration of less than 4 hours. Horizontal gradients were computed between the piezometer within the stream and the stream bank piezometer with a range of -0.16 to $0.11 \mathrm{ft} / \mathrm{ft}$, where positive values reflect groundwater movement into the stream and negative values reflect streamflow into bank storage. The mean horizontal gradient was $0.05 \mathrm{ft} / \mathrm{ft}$, and the negative values coincided with storm events for short durations. Groundwater levels, showing a seasonal change, began to slowly rise during the monitoring period, with overall increases of about $0.9 \mathrm{ft}$ within the bank piezometer and about $0.3 \mathrm{ft}$ within the groundwater system beneath the stream.

\section{Base-Flow Estimates}

GW Toolbox was used to calculate base flow along Ellerbe Creek using streamflow records for USGS streamgages EC-10 and EC-11 from October 1982 to December 2017, with a median streamflow of $41 \mathrm{ft}^{3} / \mathrm{s}$ for the 35 -year period. Gaps in the continuous streamflow record exist from May 1989 to September 1991, June 1994 to August 1994, and October 1995 to January 2006. The GW Toolbox program calculates base flow using all available data within periods between the data gaps, but the output files will not include the partial month or years with missing data in the results. Both the BFI and PART methods yielded annual and monthly estimates of base flow and surface runoff for the 35-year period.

The BFI method estimated an average annual rate of base flow of $14.0 \mathrm{ft}^{3} / \mathrm{s}$ and a base-flow index range of 0.21 to 0.49 , which means that base flow contributes between 21 and 49 percent of total streamflow annually. Estimates for base flow computed by using the PART method were less conservative, with an average annual rate of base flow of $17.7 \mathrm{ft}^{3} / \mathrm{s}$ and a maximum base-flow index of 0.57 . Annual and monthly fluctuations within the basin can be seen across the portion of the analyzed period shown in figure 8 , with the highest flows in 2009 and low flows during the drought period of 2011. The base-flow estimates using the PART method show peaks that may include interflow because they coincide with high flows attributed to frequent storm events. The average annual rate of surface runoff was estimated to be near $23 \mathrm{ft}^{3} / \mathrm{s}$ for an average contribution of nearly 60 percent of streamflow.

On the basis of provided discharge records for effluent flow from the NDWRF from 2014 to 2018, the median discharge into Ellerbe Creek is $13 \mathrm{ft}^{3} / \mathrm{s}$. Given these data, the average effluent discharge to Ellerbe Creek contributes slightly more than 30 percent of the total mean streamflow measured at the downstream USGS streamgage EC-11. On June 21, 2016, the discharge from the NDWRF outfall was stopped for about 3 hours, and the measured discharge at the USGS EC-11 streamgage dropped from 12.2 to $3.7 \mathrm{ft}^{3} / \mathrm{s}$ about 6 hours later, given the distance downstream from the outfall. The effluent discharge averaged $9.1 \mathrm{ft}^{3} / \mathrm{s}$ in the 6 hours prior to the shutoff, and the downstream EC-11 gage measured between 9.7 and $14 \mathrm{ft}^{3} / \mathrm{s}$ before flow began to decline. These data provide some insight into the natural base-flow contribution to streamflow from groundwater discharge and small tributary inflows within Ellerbe Creek, which is likely near $3.7 \mathrm{ft}^{3} / \mathrm{s}$ under similar hydrologic conditions.

\section{Water-Temperature Survey Results}

As stated previously, the interaction of shallow groundwater with surface water can be assessed by contrasting the variations in surface-water temperature resulting from seasonal and meteorological changes with the relatively stable groundwater temperature. Water-temperature surveys used to assess groundwater/surface-water interactions in Ellerbe Creek included the use of thermal imagery for locating persistent seeps along the stream bank and FO-DTS along the streambed. All data are publicly available online in Antolino (2018).

\section{Reconnaissance of Bank Seeps Using Thermal Imaging}

Reconnaissance surveys of Ellerbe Creek using a handheld FLIR camera were conducted on March 2, 2016, and July 18, 2016, to identify potential areas of groundwater discharge during seasonal extremes. The FLIR camera captures high-resolution images of real-time variations in stream and bank seep water temperature (fig. 9). During the March 2016 survey, the median surface temperatures recorded by the FLIR camera were $12.4{ }^{\circ} \mathrm{C}$ for bank inflow and $11.6{ }^{\circ} \mathrm{C}$ for the stream. During the July 2016 survey, several additional bank seeps were measured, with median surface temperatures of $23.3{ }^{\circ} \mathrm{C}$ for bank inflow and $26.5^{\circ} \mathrm{C}$ for the stream. The temperature differences between bank inflow and the stream ranged from 1.3 to $2.8^{\circ} \mathrm{C}$ for the March survey and from 1.5 to $8.3{ }^{\circ} \mathrm{C}$ for the July survey. The processed thermal images indicate six sites of potential groundwater input into the stream from the streambank where temperature differences were greater than $1.2{ }^{\circ} \mathrm{C}$ (BS-1, BS-2, BS-3, BS-4, BS-5, and BS-6; see fig. 4. for site locations). The surveys were used to identify areas of groundwater discharge for FO-DTS deployment, as well as to select water-quality sampling locations. 


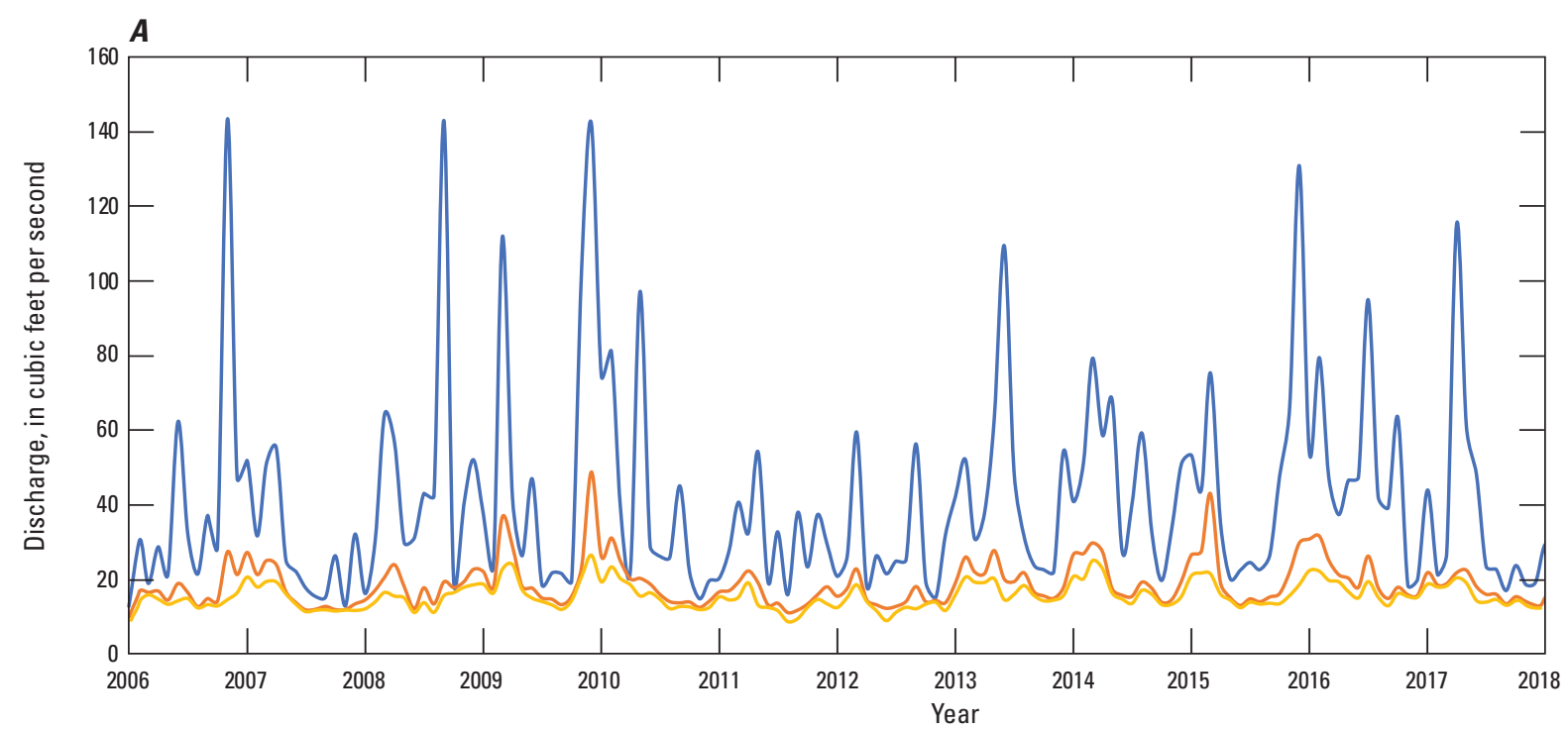

$\boldsymbol{B}$

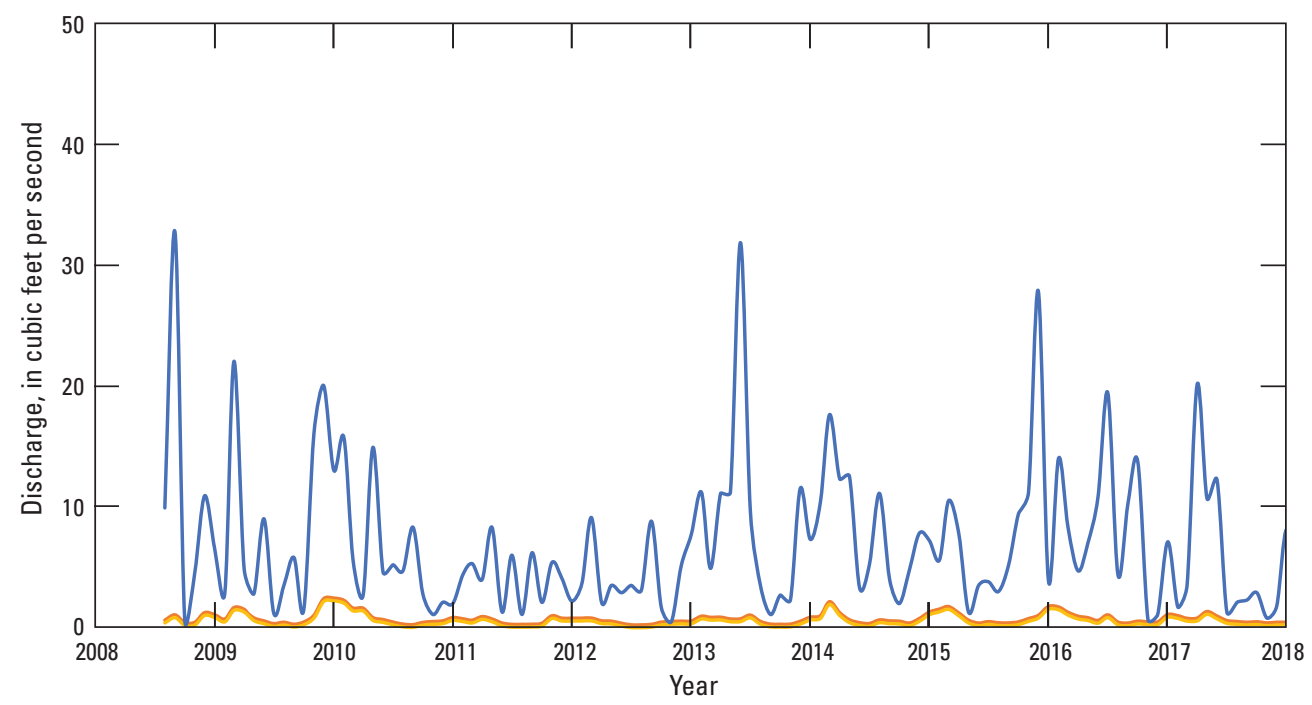

EXPLANATION

B Base flow (PART)

Base flow (BFI)

Figure 8. Graphs showing base flow estimated by using the base-flow index (BFI) and PART hydrograph separation methods for (A) U.S. Geological Survey (USGS) streamgage 02002086849 (site EC-11) and (B) USGS streamgage 0208675010 (site EC-1) in Ellerbe Creek in Durham, North Carolina. 


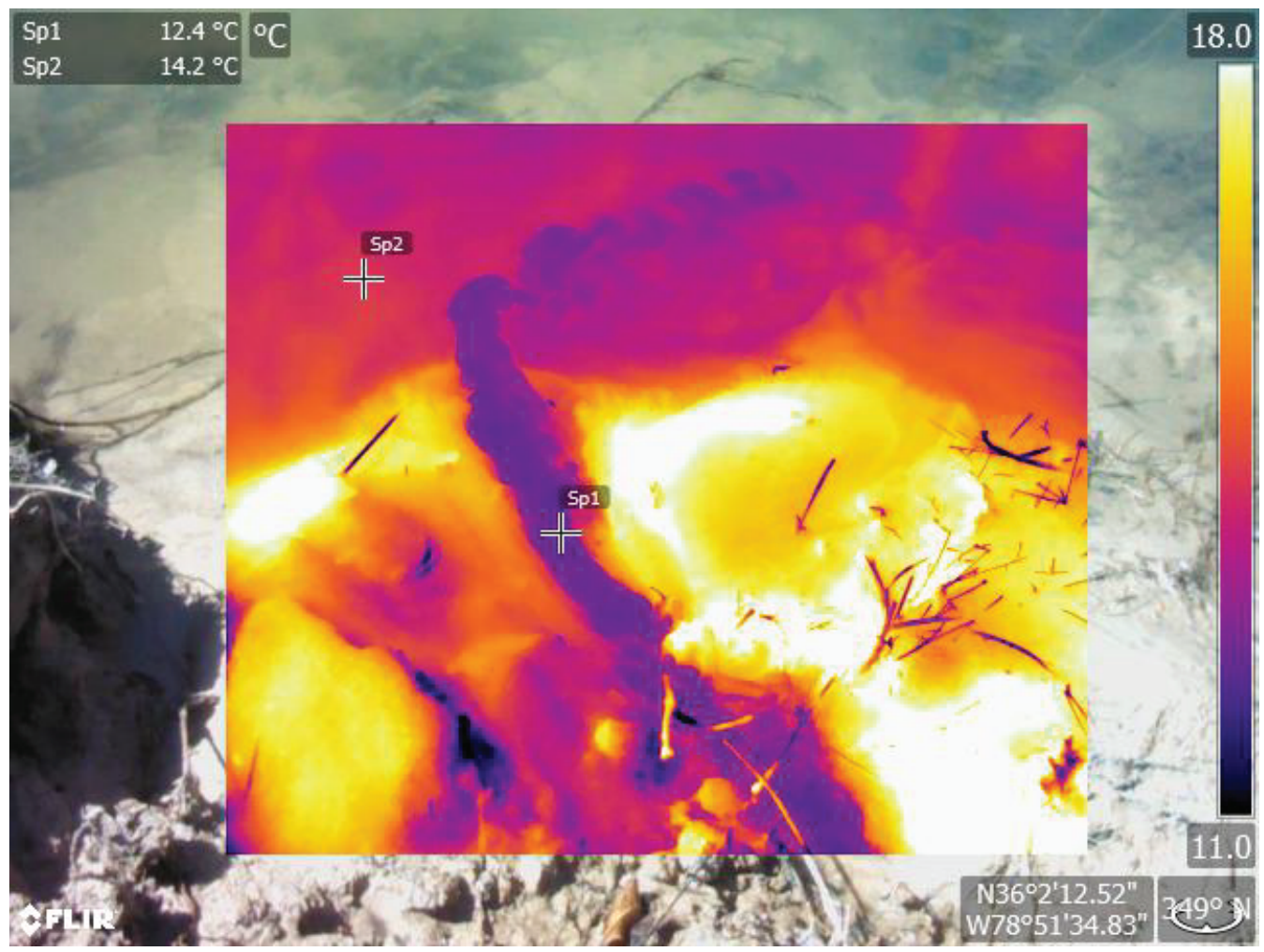

Figure 9. Example of a thermal image captured by the forward-looking infrared (FLIR) camera in March 2016 to determine stream surface and bank seep temperatures. The image was taken at bank seep BS-4 at Ellerbe Creek in Durham, North Carolina.

Thermal imagery identified several bank seeps along the study reach where water-quality samples could be taken. Temperature differences between the bank seeps and the stream were distinct enough in both winter and summer conditions to delineate inflow to Ellerbe Creek. Several of the bank seeps identified in the March 2016 survey were not observed in the July 2016 survey. Both surveys were conducted about a week after a rainfall event, so persistent groundwater seeps likely would have been flowing. During rainfall events, stream stage at the downstream USGS gage EC-11 can rise from 2 to $5 \mathrm{ft}$ above base-flow conditions. These events inundate the high, sandy-silt channel walls and contribute to shallow groundwater and bank storage. Most bank seeps observed discharging to the stream within a week of sizeable runoff events likely are sourced predominantly from bank storage. Persistent bank seeps, such as BS-1 and BS-4, may have preferential flow pathways that yield a larger groundwater component that contributes to very small but constant flow in these areas.

\section{Distributed Temperature Sensing Results}

From July 18 to 25, 2017, an FO-DTS survey was conducted in Ellerbe Creek, beginning slightly upstream from the NDWRF outfall and extending downstream from the closed municipal landfill. The streambed is mostly sand and silt for much of the reach, with exposed bedrock and boulders at the downstream end of the survey reach. The fiber-optic cable was placed within the streambed along the right bank of Ellerbe Creek to capture any discharging groundwater that may have flow paths connected to the landfill.

Streamflow recorded at the downstream USGS streamgage EC-11 during the FO-DTS survey ranged from $4.6 \mathrm{ft}^{3} / \mathrm{s}$ on July 25 to $61.8 \mathrm{ft}^{3} / \mathrm{s}$ on July 19 (fig. 6). On the night of July 18, 2017, a rainfall event of 0.64 inch was recorded during the survey. According to data collected by the NDWRF, hourly discharge from the outfall ranged from 5.6 to $20.4 \mathrm{ft}^{3} / \mathrm{s}$ and daily effluent temperatures ranged from 26.60 to $27.10^{\circ} \mathrm{C}$ during the FO-DTS survey. Local air temperature ranged from $18.8{ }^{\circ} \mathrm{C}$ on July 19 to $36.5^{\circ} \mathrm{C}$ on July 23 . The streambed temperatures measured along the reach by the FO-DTS system ranged from 21.54 to $28.53{ }^{\circ} \mathrm{C}$. Diurnal fluctuations observed within the streambed temperature data were attributed to solar radiation warming the stream each afternoon followed by cooling during the night. Areas where thermal fluctuations were reduced were assumed to be possible evidence of groundwater discharge to the stream. 
Thermal traces of streambed temperatures collected at 15-minute intervals were compared to determine areas of reduced diurnal fluctuations (fig. 10). Two ice baths were set up to quality-check the temperature readings at the upstream end of the cable (9-69 ft) and near the midpoint of the cable (1,870-2,025 ft); these areas where the cable left the streambed are shaded gray in the thermogram in figure 10 . The effects of the rainfall event that occurred late on July 18 and into the morning of July 19 can be observed in cool streambed temperatures with distinct pulses of cool runoff into the stream. Areas farthest downstream, where the stream is most shallow, had the warmest temperature signatures and largest diurnal variance.
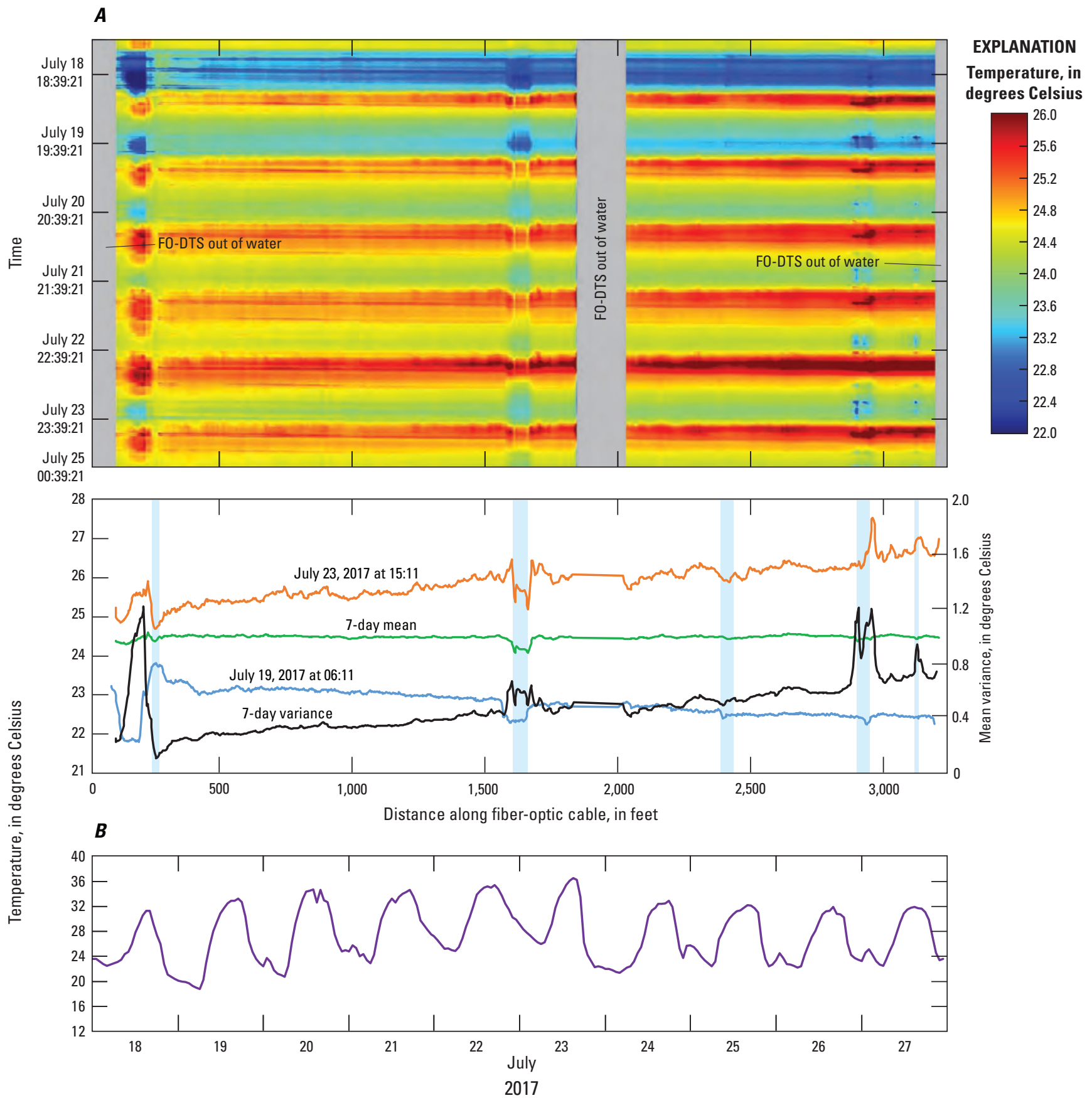

Figure 10. Distributed temperature sensing measurements collected from July 18 to 25, 2017, in Ellerbe Creek, Durham, North Carolina. $A$, Thermogram image of survey period and graph showing the 7-day mean surface-water temperature compared with warmest and coldest days/times (blue-shaded areas in the graph represent cooler inflow from groundwater or small tributaries). $B$, Graph showing recorded air temperature. FO-DTS, fiber-optic distributed temperature sensing. 
The thermal traces for the coldest day and time (July 19 at 06:11) and the warmest day and time (July 23 at 15:11) were compared with the 7-day mean for each measurement location along the cable to visualize the temperature extremes within the data. Under typical conditions, areas with small temperature variation would be locations that are thermally buffered by consistent groundwater discharge. However, it is important to consider that warm water discharged from the NDWRF outfall near the upstream end of the cable (downstream from the 230-ft cable mark) can also obscure the natural diurnal signal in this reach of Ellerbe Creek. Additional consideration should be given regarding small downstream tributaries whose sources are unaffected by the warm outfall discharge. These inflows would appear as a steady flow of slightly cooler water at the stream confluence, yielding a similar signature to that of cooler groundwater discharge to the stream.

Areas where the thermal signature shows small temperature variability are highlighted in blue in the plot below the thermogram in figure 10 . The five most prominent of these areas on the thermogram were at distances of 255-272, 1,591-1,667, 2,395-2,408, 2,933-2,946, and $3,057-3,071 \mathrm{ft}$ from the upstream end of the cable. The area between 255 and $272 \mathrm{ft}$ corresponds with the NDWRF outfall, where the thermal signature shows a consistently warm inflow to the stream (fig. 11). At the area near the 1,591-ft mark, a small persistent seep was observed at the bank (BS-5), behind a sandbar formed during recent stormflow. Several loops of cable were wound at this location to ensure any temperature difference from the inflow was captured by the survey. This site is likely a small discharge point for shallow groundwater to the stream. Three small unnamed tributaries to Ellerbe Creek are at cable distances of 2,395-2,408, 2,933-2,946, and 3,057-3,071 ft. It appears that stream depth may explain the difference in variability of thermal signatures at these locations. The tributary at 2,395 $\mathrm{ft}$ enters the stream through a culvert where the stream depth is about $3.9 \mathrm{ft}$, whereas the tributaries farther downstream at 2,933 and 2,946 ft enter at a stream depth of only about $0.65 \mathrm{ft}$ (fig. 11). Cooler inflow was observed at all three tributaries after the rain event on July 18, 2017. The farthest downstream tributaries were exposed to the air as stream stage dropped after the storm event, as can be seen in the increasing temperature extremes from day to night across the monitoring period shown on the thermogram.

Low levels of groundwater discharge to the stream may explain the lack of distinctive discharge areas captured in the FO-DTS survey data. The groundwater seep at the 1,591-ft mark likely was detected because of its location behind a sandbar, where it was shielded from the higher and warmer flows of the stream. Groundwater discharge from bank seeps is small compared to the overall streamflow; therefore, the FO-DTS survey was not able to resolve groundwater discharge through the streambed within Ellerbe Creek. Using the FO-DTS method, Briggs and others (2012) were able to resolve groundwater contributions along a 900-meter stream reach discharging at a rate near 5 percent of the overall streamflow. Lauer and others (2013) were able to resolve simulated groundwater inflow to a stream at a rate near 2 percent of the streamflow in a mountain creek. Likely, most of the remaining contributions to streamflow come from recently recharged shallow groundwater that discharges farther upgradient into the small tributaries along Ellerbe Creek. 


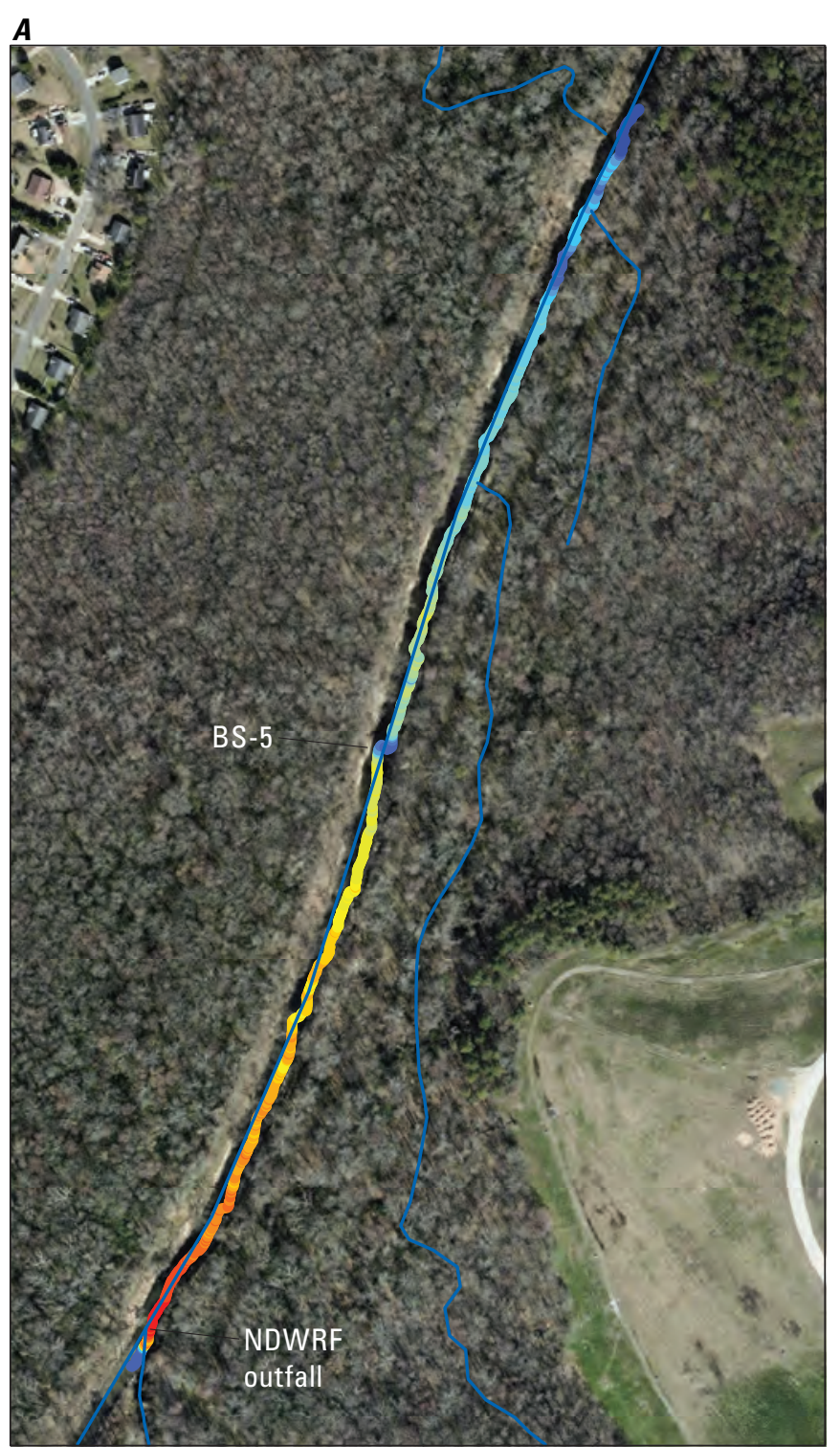

Base from North Carolina Center for Geographic Information and Analysis EXPLANATION North Carolina State Plane coordinate system North American Datum of 1983

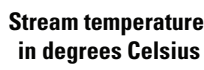

\section{$B$}

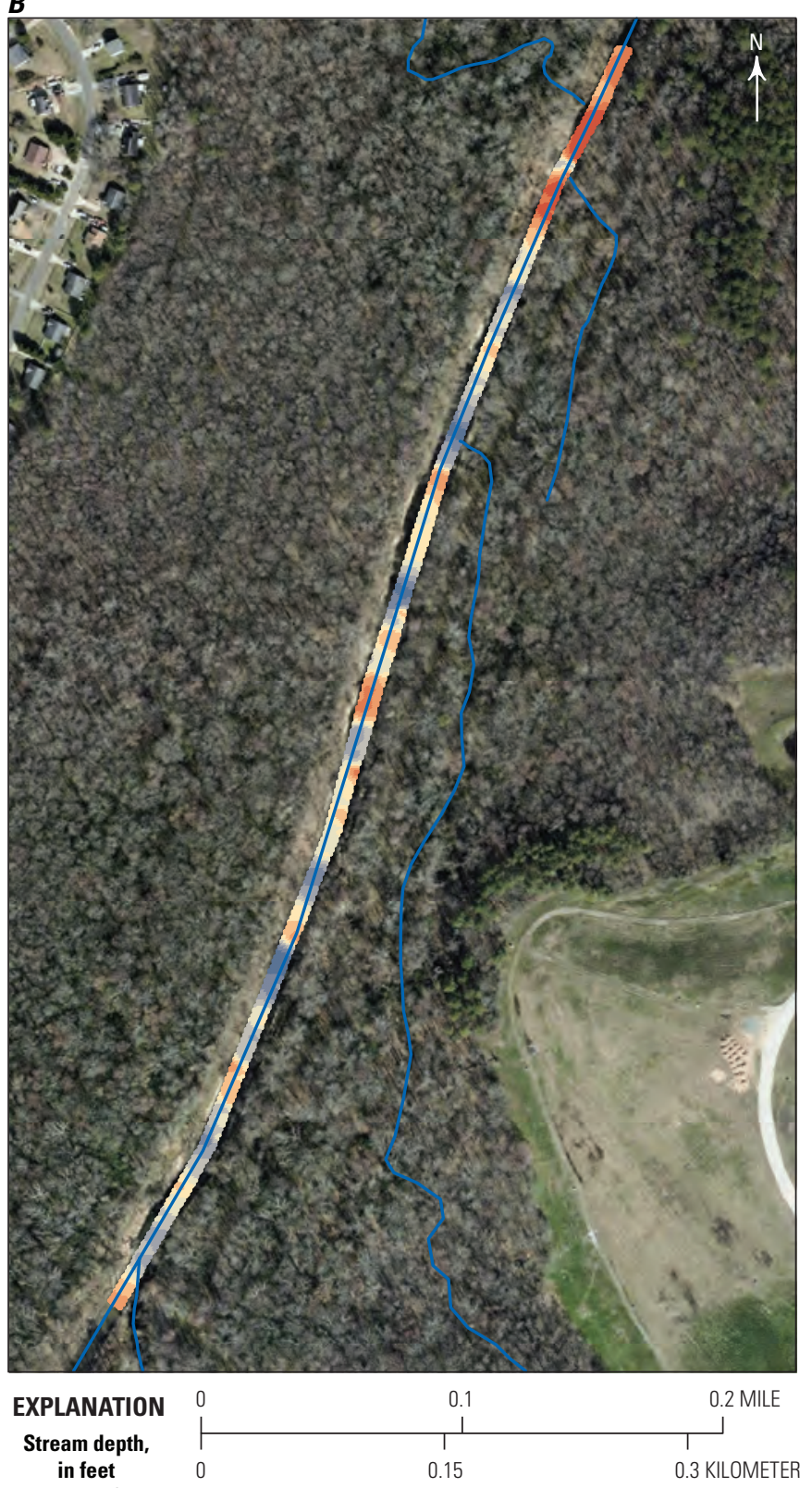

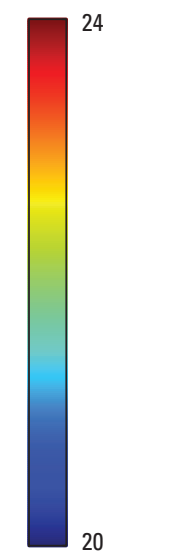

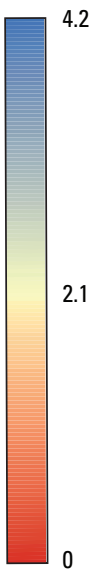

Figure 11. Maps showing $(A)$ mean distributed temperature sensing measurements collected from July 18 , 2017, to July 25,2017 , and (B) stream depth measurements collected with an acoustic Doppler current profiler during base-flow conditions on July 27, 2017, at Ellerbe Creek in Durham, North Carolina. BS, bank seep; NDWRF, North Durham Water Reclamation Facility. 


\section{Water-Quality Results}

Water-quality sampling within the study area provided information to help identify possible sources of nutrients into Ellerbe Creek and ultimately Falls Lake. Periodic waterquality samples were collected at 11 sites along Ellerbe Creek during July 2016 and March 2018 (tables 5 and 6). Shallow groundwater seeps along the stream bank were sampled at six locations in August 2016 and July 2017. Two groundwater monitoring wells and two piezometers were sampled in March 2018. Quality-assurance sample results for the three replicates generally signified good analytical precision, with two of the replicates having less than a 10-percent difference from the original sample. Five blank samples were collected, and results were generally below reporting limits for all samples, except for one field blank sample collected in August 2016 that had a total nitrogen concentration of $0.11 \mathrm{mg} / \mathrm{L}$. On the basis of guidelines provided in Mueller and others (2015), associated samples collected during the August 2016 sampling event were considered valid only if the concentration exceeded five times the amount detected in the blank, in this case, $0.55 \mathrm{mg} / \mathrm{L}$ of total nitrogen.

The temperature of surface-water samples ranged from 24.4 to $27.2^{\circ} \mathrm{C}$ for the July 2016 sampling and 7.0 to $13.1^{\circ} \mathrm{C}$ for the March 2018 sampling. The temperature of bank seep samples ranged from 21.6 to $28.8^{\circ} \mathrm{C}$ during the summer sampling events in August 2016 and July 2017. The temperature of groundwater samples ranged from $13.1^{\circ} \mathrm{C}$ in $\mathrm{GW}-2$ to $22.8^{\circ} \mathrm{C}$ in $\mathrm{GW}-1$. Specific conductance values ranged from 29 microsiemens per centimeter $(\mu \mathrm{S} / \mathrm{cm})$ at the upstream surface-water site EC-2 to $461 \mu \mathrm{S} / \mathrm{cm}$ at the bank seep BS-3. The high specific conductance measured at BS-3 on August 2, 2016, may be attributed to high sodium and bicarbonate (or alkalinity) concentrations at the site, both of which were the highest concentrations of all samples collected in the study. Generally, the groundwater samples had noticeably lower specific conductance than the surfacewater samples. Values for $\mathrm{pH}$ ranged from 5.1 to 7.4 and were generally higher within surface water than in groundwater. Dissolved oxygen ranged from 7.1 to $10.6 \mathrm{mg} / \mathrm{L}$ for the surface-water samples and 1.6 to $9.3 \mathrm{mg} / \mathrm{L}$ for the groundwater samples. Field measurements of dissolved oxygen for the bank seeps did not meet precision standards for inclusion in the study.

Relative distribution of major ions in water samples is shown on a Piper diagram (fig. 12). Water rich in calciumbicarbonate upstream from the NDWRF outfall roughly trended toward water dominated by sodium-sulfate with a slight rise in chloride downstream from the outfall. Nitrate concentrations in surface-water samples increased slightly between July 2016 and March 2018. The three bank seeps sampled for major ions (BS-1, BS-3, and BS-4) represented a range of water types, with BS-4 being the most similar to the Ellerbe Creek samples. BS-4 had the highest sodium concentration of all samples collected during the study at $82.9 \mathrm{mg} / \mathrm{L}$. The water types for the two groundwater monitoring wells differ from one another, with GW-1 containing higher concentrations of dissolved constituents, especially iron, and more than twice the amount of nutrients as seen in GW-2. This relative dilution observed in GW-2 may be due to some degree of hydraulic communication with a nearby retention pond that is upgradient from the well (fig. 4). GW-1 had the highest calcium, magnesium, bicarbonate, and chloride concentrations of all sampled sites at 33.4, 14.2, 102, and $39.2 \mathrm{mg} / \mathrm{L}$, respectively. The sample collected from the small tributary 0.55 kilometer downstream from the outfall, site TR-1, shows a water type that plots near the midpoint of all surface-water samples.

Boxplots were constructed for specific conductance, $\mathrm{pH}$, and nutrient concentrations of the surface-water, bank seep, and groundwater sites (fig. 13). Ammonia concentrations ranged from below the method detection level of $0.01 \mathrm{mg} / \mathrm{L}$ (BS-4, PZ-2, and GW-2) to $0.46 \mathrm{mg} / \mathrm{L}$ in bank seep BS-2. Concentrations of nitrate ranged from below the method detection level of $0.04 \mathrm{mg} / \mathrm{L}$ (bank seeps BS-1, BS-3, and BS-4) to $2.69 \mathrm{mg} / \mathrm{L}$ at surface-water site EC-3, $215 \mathrm{ft}$ downstream from the NDWRF outfall (figs. 14-16). The median nitrate concentration in the surface-water samples was an order of magnitude higher than that of the groundwater samples.

Nitrate was detected in all surface-water samples, with the lowest concentration of $0.38 \mathrm{mg} / \mathrm{L}$ observed upstream from the NDWRF outfall. Surface-water samples collected in July 2016 did not have a strong spatial pattern. The March 2018 samples had higher nitrate concentrations near the NDWRF and became more diluted moving downstream. Samples collected from tributary inflows contained low levels of nitrate, with concentrations ranging from 0.16 to $0.41 \mathrm{mg} / \mathrm{L}$. Samples collected from shallow bank seeps along the stream did not have elevated nitrate concentrations; several were below the method detection level, and the highest concentration was $0.406 \mathrm{mg} / \mathrm{L}$. The bank seep BS-5, which was identified in the FO-DTS survey, had a nitrate concentration of $0.14 \mathrm{mg} / \mathrm{L}$. The sample collected at the streambed piezometer (PZ-1) had a nitrate concentration of $1.04 \mathrm{mg} / \mathrm{L}$, which is likely due to downward surface-water seepage through the streambed. Neither the groundwater monitoring wells nor the bank piezometer sample had nutrient concentrations over $0.10 \mathrm{mg} / \mathrm{L}$. Higher nitrate concentrations are typically found within groundwater when ammonium and dissolved oxygen are abundant, whereas denitrification via bacteria within the aquifer can reduce nitrate to nitrogen gas when adequate amounts of dissolved oxygen are not available. The GW-1 and PZ-1 samples had ammonia concentrations between 0.10 and $0.02 \mathrm{mg} / \mathrm{L}$, likely the result of natural organic matter decay along the flow path toward the stream. All samples had total nitrogen concentrations below the Falls Lake Nutrient Strategy Stage I mass limit of $3.09 \mathrm{mg} / \mathrm{L}$, except for one stream sample (EC-3) immediately downstream from the NDWRF outfall, which had a total nitrogen concentration of $3.23 \mathrm{mg} / \mathrm{L}$ in March 2018. 
Table 5. Temperature, specific conductance, dissolved oxygen, pH, and nutrient concentrations of water-quality samples collected at Ellerbe Creek, Durham, North Carolina, from July 2016 to March 2018.

[Locations of sample sites are shown in figure $4 .{ }^{\circ} \mathrm{C}$, degree Celsius; $\mathrm{mg} / \mathrm{L}$, milligram per liter; $\mu \mathrm{S} / \mathrm{cm}$, microsiemens per centimeter; $\mathrm{N}$, nitrogen; P, phosphorus; EC, Ellerbe Creek; TR, tributary; BS, bank seep; -, not measured; <, less than; PZ, piezometer; GW, groundwater well]

\begin{tabular}{|c|c|c|c|c|c|c|c|c|c|c|c|c|c|}
\hline Station number & $\begin{array}{c}\text { Site } \\
\text { map } \\
\text { name }\end{array}$ & $\begin{array}{l}\text { Sample } \\
\text { date }\end{array}$ & $\begin{array}{l}\text { Sample } \\
\text { time }\end{array}$ & $\begin{array}{c}\text { Temperature, } \\
{ }^{\circ} \mathrm{C}\end{array}$ & $\begin{array}{l}\text { Dissolved } \\
\text { oxygen, } \\
\text { mg/L }\end{array}$ & $\begin{array}{l}\text { Dissolved } \\
\text { oxygen } \\
\text { saturation, } \\
\text { percent }\end{array}$ & $\begin{array}{c}\text { pH, } \\
\text { standard } \\
\text { units }\end{array}$ & $\begin{array}{c}\text { Specific } \\
\text { conductance, } \\
\mu S / c m\end{array}$ & $\begin{array}{c}\text { Ammonia, } \\
\mathrm{mg} / \mathrm{L} \\
\text { as } \mathrm{N}\end{array}$ & $\begin{array}{c}\text { Nitrate } \\
\text { plus nitrite, } \\
\text { mg/L } \\
\text { as N }\end{array}$ & $\begin{array}{c}\text { Nitrite, } \\
\text { mg/L } \\
\text { as } \mathbf{N}\end{array}$ & $\begin{array}{c}\text { Orthophosphate, } \\
\text { mg/L } \\
\text { as } \mathrm{P}\end{array}$ & $\begin{array}{c}\text { Total N, } \\
\text { mg/L }\end{array}$ \\
\hline 0208682450 & EC-2 & $7 / 12 / 2016$ & $09: 45$ & 24.4 & 7.1 & 85.2 & 7.4 & 29 & 0.14 & 0.381 & 0.022 & 0.039 & 1.02 \\
\hline 02086833 & $\mathrm{EC}-3$ & $7 / 12 / 2016$ & $10: 25$ & 24.9 & 7.5 & 90.9 & 7.3 & 390 & 0.07 & 1.17 & 0.031 & 0.043 & 1.73 \\
\hline 02086835 & EC-5 & $7 / 12 / 2016$ & $11: 00$ & 25.3 & 7.5 & 91.6 & 7.3 & 393 & 0.06 & 1.41 & 0.035 & 0.037 & 2.06 \\
\hline 360211078513701 & TR-1 & $7 / 12 / 2016$ & $11: 20$ & 25.5 & 7.4 & 90.7 & 7.3 & 156 & 0.04 & 0.273 & 0.007 & 0.048 & 0.88 \\
\hline 02086837 & EC-6 & $7 / 12 / 2016$ & $11: 45$ & 25.7 & 7.5 & 92.2 & 7.3 & 378 & 0.06 & 1.33 & 0.032 & 0.037 & 1.92 \\
\hline 02086839 & EC-7 & $7 / 12 / 2016$ & $13: 00$ & 26.1 & 8 & 99.1 & 7.4 & 381 & 0.06 & 1.21 & 0.03 & 0.04 & 1.82 \\
\hline 360226078512801 & TR-2 & $7 / 12 / 2016$ & $13: 10$ & 25.7 & 7.3 & 89.8 & 7.2 & 131 & 0.06 & 0.164 & 0.007 & 0.032 & 0.78 \\
\hline 02086841 & EC-8 & $7 / 12 / 2016$ & $15: 20$ & 27.2 & 8.1 & 100 & 7.3 & 398 & 0.04 & 1.18 & 0.014 & 0.035 & 1.84 \\
\hline 02086843 & EC-9 & $7 / 12 / 2016$ & $14: 10$ & 26.9 & 8 & 100 & 7.4 & 380 & 0.05 & 1.22 & 0.029 & 0.039 & 1.78 \\
\hline 02086845 & EC-10 & $7 / 12 / 2016$ & $14: 40$ & 27.1 & 8 & 100 & 7.4 & 379 & 0.05 & 1.21 & 0.03 & 0.038 & 1.79 \\
\hline 360149078514801 & BS-1 & $8 / 2 / 2016$ & $11: 00$ & 22.2 & - & - & 5.9 & 100 & 0.12 & 0.406 & 0.003 & 0.041 & 0.85 \\
\hline 360159078514101 & BS-3 & $8 / 2 / 2016$ & $12: 15$ & 28.8 & - & - & 7.1 & 461 & 0.11 & $<0.040$ & 0.001 & 0.065 & 0.39 \\
\hline 360204078513901 & BS-4 & $8 / 2 / 2016$ & $12: 45$ & 21.6 & - & - & 5.6 & 147 & $<0.01$ & 0.203 & $<0.001$ & 0.01 & 0.28 \\
\hline 360149078514801 & BS-1 & $7 / 27 / 2017$ & $13: 15$ & 26.2 & - & - & 6.7 & 117 & 0.1 & $<0.040$ & $<0.001$ & 0.019 & - \\
\hline 360159078514101 & BS-3 & $7 / 27 / 2017$ & $10: 15$ & 27.1 & - & - & 6.6 & 170 & 0.05 & 0.062 & 0.002 & 0.007 & - \\
\hline 360204078513901 & BS-4 & $7 / 27 / 2017$ & $10: 50$ & 26.1 & - & - & 5.9 & 150 & 0.03 & 0.111 & 0.002 & 0.011 & - \\
\hline 360158078514201 & BS-2 & $7 / 27 / 2017$ & 09:40 & 26.4 & - & - & 6.5 & 160 & 0.46 & $<0.040$ & 0.003 & 0.01 & 0.75 \\
\hline 360205078513801 & BS-5 & $7 / 27 / 2017$ & $11: 20$ & 26.2 & - & - & 6.1 & 80 & 0.03 & 0.136 & 0.001 & 0.009 & - \\
\hline 360207078513801 & BS-6 & $7 / 27 / 2017$ & $12: 10$ & 26.2 & - & - & 6 & 100 & 0.11 & 0.043 & 0.009 & 0.018 & - \\
\hline 02086833 & EC-3 & $3 / 27 / 2018$ & $09: 30$ & 13.1 & 9.7 & 92.1 & 7.0 & 328 & 0.03 & 2.69 & 0.007 & 0.013 & 3.23 \\
\hline 360211078513701 & TR-1 & $3 / 27 / 2018$ & $11: 00$ & 7.0 & 10.6 & 87.2 & 7.2 & 204 & 0.04 & 0.41 & 0.003 & 0.016 & 0.94 \\
\hline 02086837 & EC-6 & $3 / 27 / 2018$ & $11: 30$ & 12.3 & 10 & 93.3 & 7.0 & 320 & 0.03 & 2.27 & 0.006 & 0.014 & 2.79 \\
\hline 02086849 & $\mathrm{EC}-11$ & $3 / 27 / 2018$ & $12: 15$ & 10.4 & 10.2 & 91.1 & 7.2 & 279 & 0.11 & 2.19 & 0.02 & 0.016 & 2.75 \\
\hline 360204078513902 & PZ-1 & $3 / 29 / 2018$ & $15: 20$ & 21.3 & 9.3 & 100 & 6.1 & 144 & 0.19 & 0.067 & 0.002 & 0.023 & 0.51 \\
\hline 360204078513903 & PZ-2 & $3 / 29 / 2018$ & $15: 30$ & 22.4 & 8.9 & 100 & 6.3 & 298 & $<0.01$ & 1.04 & $<0.001$ & 0.005 & 1.17 \\
\hline 360159078513801 & GW-1 & $3 / 29 / 2018$ & $11: 00$ & 22.8 & 1.6 & 18.8 & 5.2 & 186 & 0.11 & 0.105 & 0.006 & 0.044 & 0.65 \\
\hline 360207078512501 & GW-2 & $3 / 29 / 2018$ & $14: 00$ & 13.1 & 4.9 & 74.2 & 5.1 & 119 & $<0.01$ & 0.048 & $<0.001$ & 0.004 & 0.15 \\
\hline
\end{tabular}


Table 6. Major ion concentrations in water-quality samples collected at Ellerbe Creek, Durham, North Carolina, from July 2016 to March 2018.

[Locations of sample sites are shown in figure 4. mg/L, milligram per liter; $\mathrm{CaCO}_{3}$, calcium carbonate; $\mu \mathrm{g} / \mathrm{L}$; microgram per liter; EC, Ellerbe Creek; - , not measured; BS, bank seep; TR, tributary; GW, groundwater well; <, less than]

\begin{tabular}{|c|c|c|c|c|c|c|c|c|c|c|c|c|c|c|c|c|}
\hline Station number & $\begin{array}{c}\text { Site } \\
\text { map } \\
\text { name }\end{array}$ & $\begin{array}{c}\text { Sample } \\
\text { date }\end{array}$ & $\begin{array}{c}\text { Sample } \\
\text { time }\end{array}$ & $\begin{array}{c}\text { Dissolved } \\
\text { solids, } \\
\text { mg/L }\end{array}$ & $\begin{array}{c}\text { Calcium, } \\
\mathrm{mg} / \mathrm{L}\end{array}$ & $\begin{array}{c}\text { Magne- } \\
\text { sium, } \\
\text { mg/L }\end{array}$ & $\begin{array}{l}\text { Potas- } \\
\text { sium, } \\
\mathrm{mg} / \mathrm{L}\end{array}$ & $\begin{array}{c}\text { Sodium, } \\
\text { mg/L }\end{array}$ & $\begin{array}{l}\text { Chlo- } \\
\text { ride, } \\
\mathrm{mg} / \mathrm{L}\end{array}$ & $\begin{array}{c}\text { Sulfate, } \\
\text { mg/L }\end{array}$ & $\begin{array}{c}\text { Bicarbon- } \\
\text { ate, } \\
\mathrm{mg} / \mathrm{L}\end{array}$ & $\begin{array}{c}\text { Alkalinity, } \\
\mathrm{mg} / \mathrm{L} \text { as } \\
\mathrm{CaCO}_{3}\end{array}$ & $\begin{array}{c}\text { Bro- } \\
\text { mide, } \\
\text { mg/L }\end{array}$ & $\begin{array}{c}\text { Fluoride, } \\
\mathrm{mg} / \mathrm{L}\end{array}$ & $\begin{array}{l}\text { Iron, } \\
\mu g / L\end{array}$ & $\begin{array}{c}\text { Manga- } \\
\text { nese, } \\
\mu \mathrm{g} / \mathrm{L}\end{array}$ \\
\hline 0208682450 & EC-2 & $7 / 12 / 2016$ & $09: 45$ & 200 & 28.7 & 7.16 & 4.49 & 18.9 & 17.4 & 13.6 & 125.66 & 103 & - & 0.16 & 604 & 205 \\
\hline 02086833 & EC-3 & $7 / 12 / 2016$ & $10: 25$ & 227 & 23.7 & 6.11 & 7.62 & 39.2 & 33 & 34.1 & 109.56 & 89.8 & - & 0.32 & 304 & 93.5 \\
\hline 02086835 & EC-5 & $7 / 12 / 2016$ & $11: 00$ & 243 & 21.9 & 5.8 & 8.58 & 45.6 & 37.6 & 39.8 & 104.19 & 85.4 & - & 0.38 & 205 & 61.2 \\
\hline 02086837 & EC-6 & $7 / 12 / 2016$ & $11: 45$ & 247 & 22.1 & 5.91 & 8.25 & 43.9 & 35.9 & 37.7 & 105.042 & 86.1 & - & 0.35 & 225 & 73.8 \\
\hline 02086839 & EC-7 & $7 / 12 / 2016$ & $13: 00$ & 237 & 22.7 & 6.03 & 7.98 & 42.3 & 34.6 & 35.9 & 106.262 & 87.1 & - & 0.34 & 265 & 74.4 \\
\hline 02086841 & EC-8 & $7 / 12 / 2016$ & $15: 20$ & 233 & 20.9 & 5.64 & 8.74 & 47 & 39.1 & 40.9 & 101.75 & 83.4 & - & 0.39 & 186 & 50.8 \\
\hline 02086843 & EC-9 & $7 / 12 / 2016$ & $14: 10$ & 218 & 22.5 & 5.87 & 7.94 & 42 & 34.8 & 36.1 & 105.77 & 86.7 & - & 0.34 & 247 & 66.1 \\
\hline 02086845 & EC-10 & $7 / 12 / 2016$ & $14: 40$ & 219 & 22.4 & 5.92 & 8.1 & 41.4 & 34.7 & 36.1 & 105.53 & 86.5 & - & 0.34 & 264 & 67.3 \\
\hline 360149078514801 & BS-1 & $8 / 2 / 2016$ & $11: 00$ & 71 & 8.02 & 2.17 & 1.81 & 7.47 & 3.28 & 6.21 & 42.09 & 34.5 & 0.04 & 0.06 & 1,150 & 596 \\
\hline 360159078514101 & BS-3 & $8 / 2 / 2016$ & $12: 15$ & 296 & 20.2 & 5.43 & 1.82 & 82.9 & 25.5 & 11.7 & 258.64 & 212 & 0.252 & 0.16 & 562 & 968 \\
\hline 360204078513901 & BS-4 & $8 / 2 / 2016$ & $12: 45$ & 97 & 7.56 & 3.6 & 0.57 & 15.8 & 6.8 & 33 & 28.79 & 23.6 & 0.056 & 0.04 & 95.4 & 10.6 \\
\hline 02086833 & EC-3 & $3 / 27 / 2018$ & 09:30 & - & 20.1 & 5.19 & 7.32 & 36.3 & 37.5 & 35.3 & 62.8 & 51.6 & 0.069 & - & 187 & - \\
\hline 360211078513701 & TR-1 & $3 / 27 / 2018$ & $11: 00$ & - & 17.9 & 4.95 & 2.12 & 17.3 & 21.4 & 14.1 & 65.9 & 54.1 & 0.084 & - & 438 & - \\
\hline 02086837 & EC-6 & $3 / 27 / 2018$ & $11: 30$ & - & 20.2 & 5.2 & 7.11 & 35.2 & 36.7 & 33.9 & 75.6 & 62.2 & 0.09 & - & 209 & - \\
\hline 02086849 & EC-11 & $3 / 27 / 2018$ & $12: 15$ & - & 19.4 & 5.01 & 5.86 & 28.9 & 30.2 & 27.5 & 65.7 & 54 & 0.06 & - & 233 & - \\
\hline 360159078513801 & GW-1 & $3 / 29 / 2018$ & $11: 00$ & - & 33.4 & 14.2 & 1.13 & 10.5 & 39.2 & 8.25 & 102 & 83.4 & 0.479 & - & 4,260 & - \\
\hline 360207078512501 & GW-2 & $3 / 29 / 2018$ & $14: 00$ & - & 12.6 & 4.13 & 0.33 & 17.9 & 37 & 6.82 & 31.2 & 25.5 & 0.239 & - & $<10.0$ & - \\
\hline
\end{tabular}




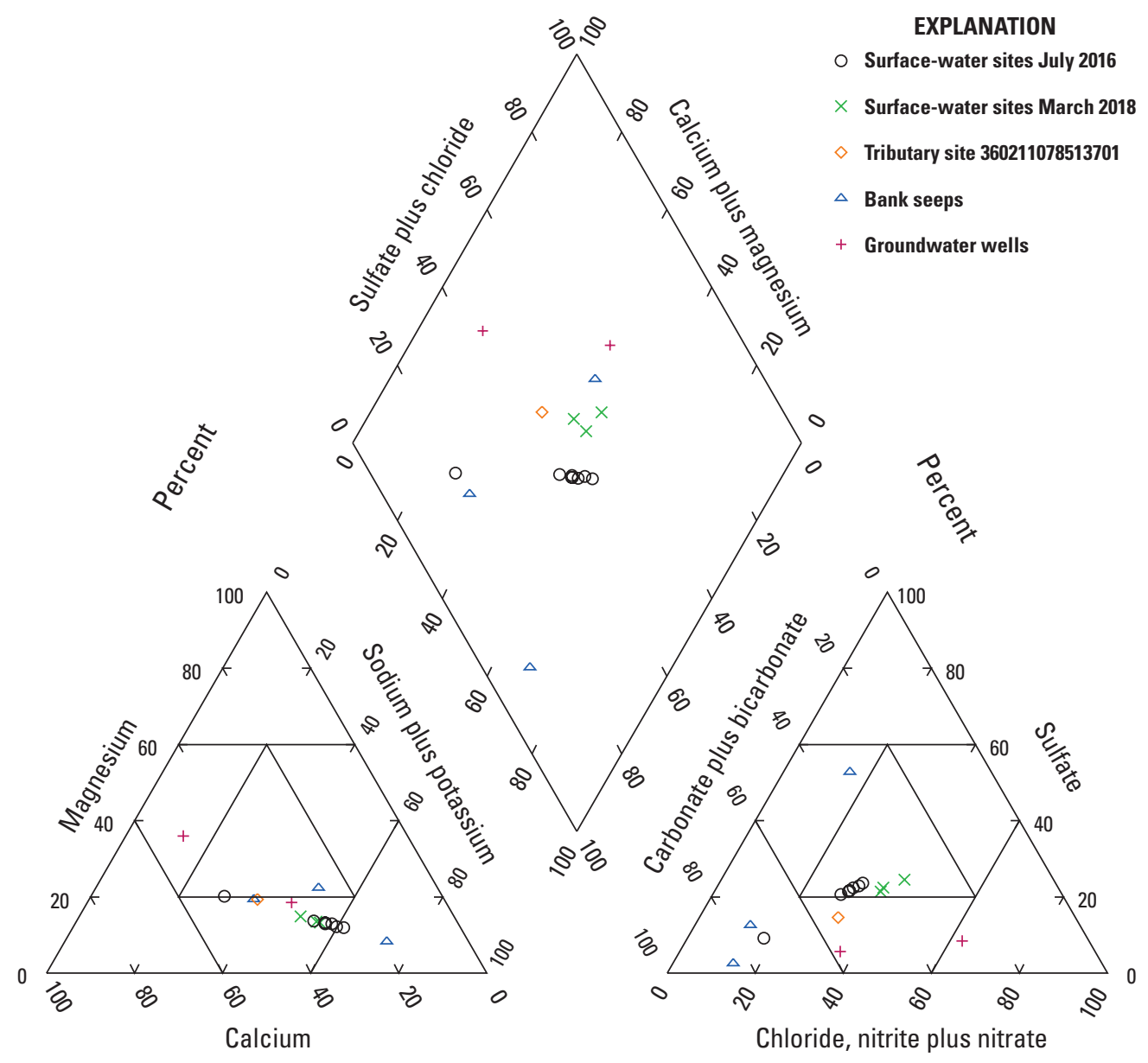

Figure 12. Trilinear Piper diagram showing water-chemistry data for water-quality samples collected in July 2016 and March 2018 at surface-water sites, bank seeps, and groundwater wells in the Ellerbe Creek study area, Durham, North Carolina.

On the basis of the low nitrate concentrations within the groundwater samples, the small source of nitrate observed within the bank seeps and tributaries may be attributed to Ellerbe Creek itself. In response to rainfall events, rising stage from storm flow recharges bank storage with diluted stream water and likely produces some degree of backwater within the tributaries. As stream stage falls and hydraulic gradients begin to reverse to base-flow conditions, the inundated banks discharge back into Ellerbe Creek. In other settings where stream waters do not contain elevated nitrate concentrations, discharge from bank storage can dilute the nutrient signature of the groundwater discharging to a stream. Given the nutrient concentrations within Ellerbe Creek, however, this likely is not the case. The bank storage component, which is filled from recent storm events, is more likely to contain the high nutrient concentrations. Similar studies have shown that where effluent discharge constitutes a majority of base flow, it may also exert a dominant influence on stream water-quality (Harden and others, 2013; Lambert and others, 2017). 

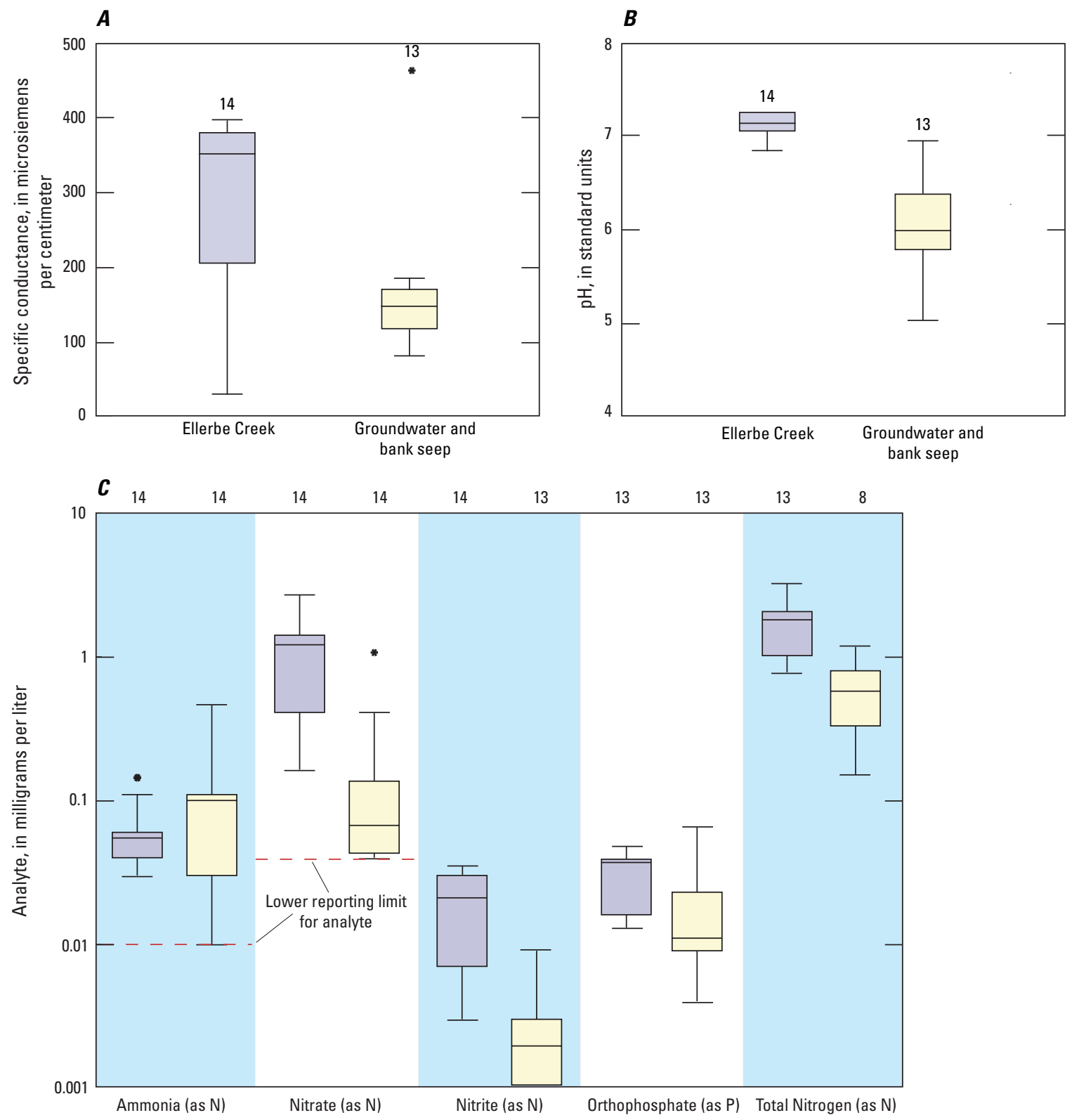

\section{EXPLANATION}

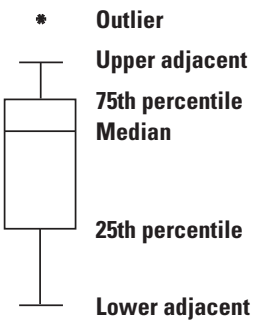

Figure 13. Boxplots showing range, median, and quartile statistical values for $(A)$ specific conductance, $(B) \mathrm{pH}$, and $(C)$ nutrient concentrations of surface-water, groundwater, and bank seep samples collected in July and August 2016, July 2017, and March 2018 in the Ellerbe Creek study area in Durham, North Carolina. N, nitrogen; P, phosphorous. 


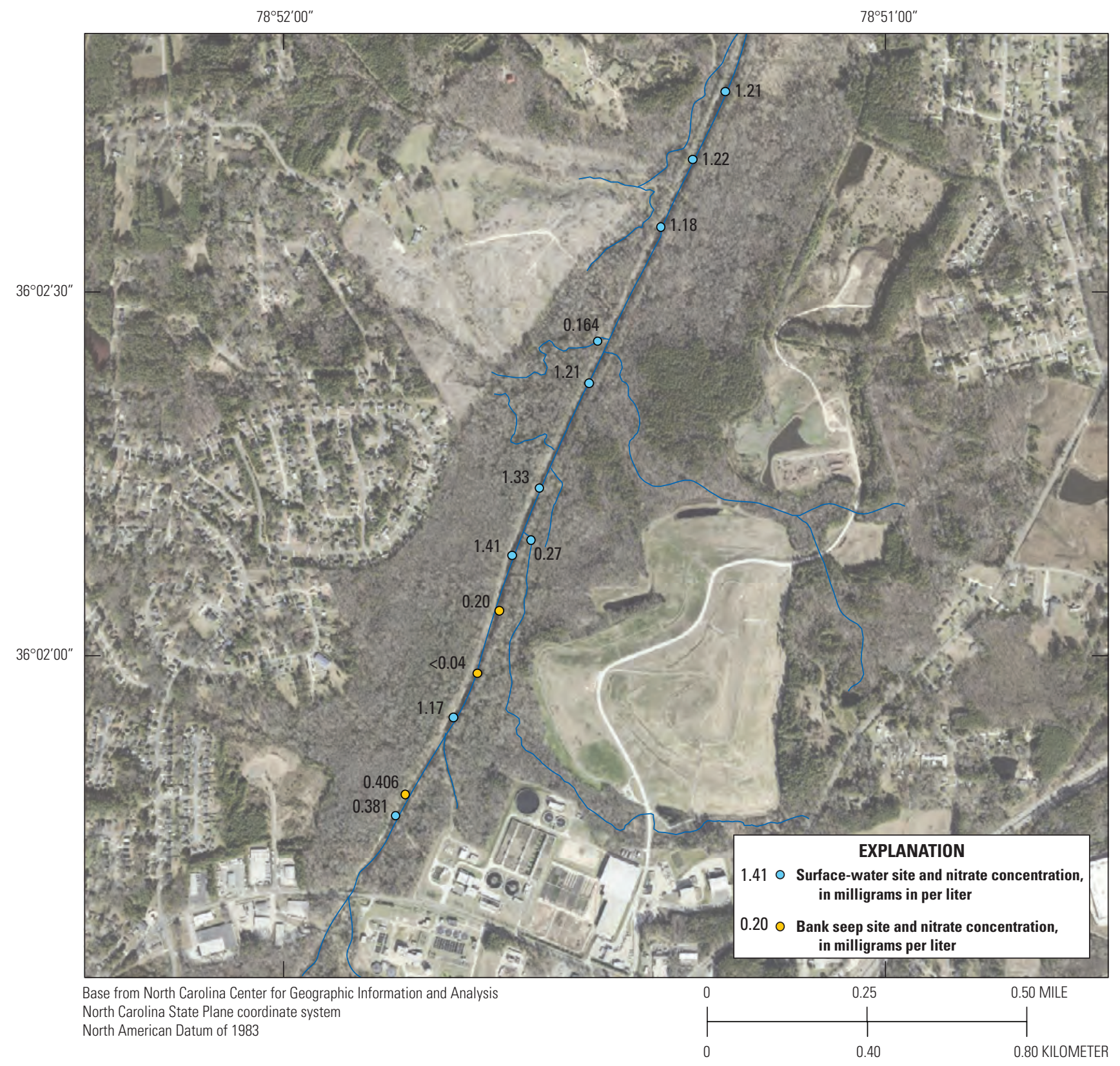

Figure 14. Map showing nitrate concentrations at surface-water and bank seep sites sampled in July and August 2016 in the Ellerbe Creek study area in Durham, North Carolina. 


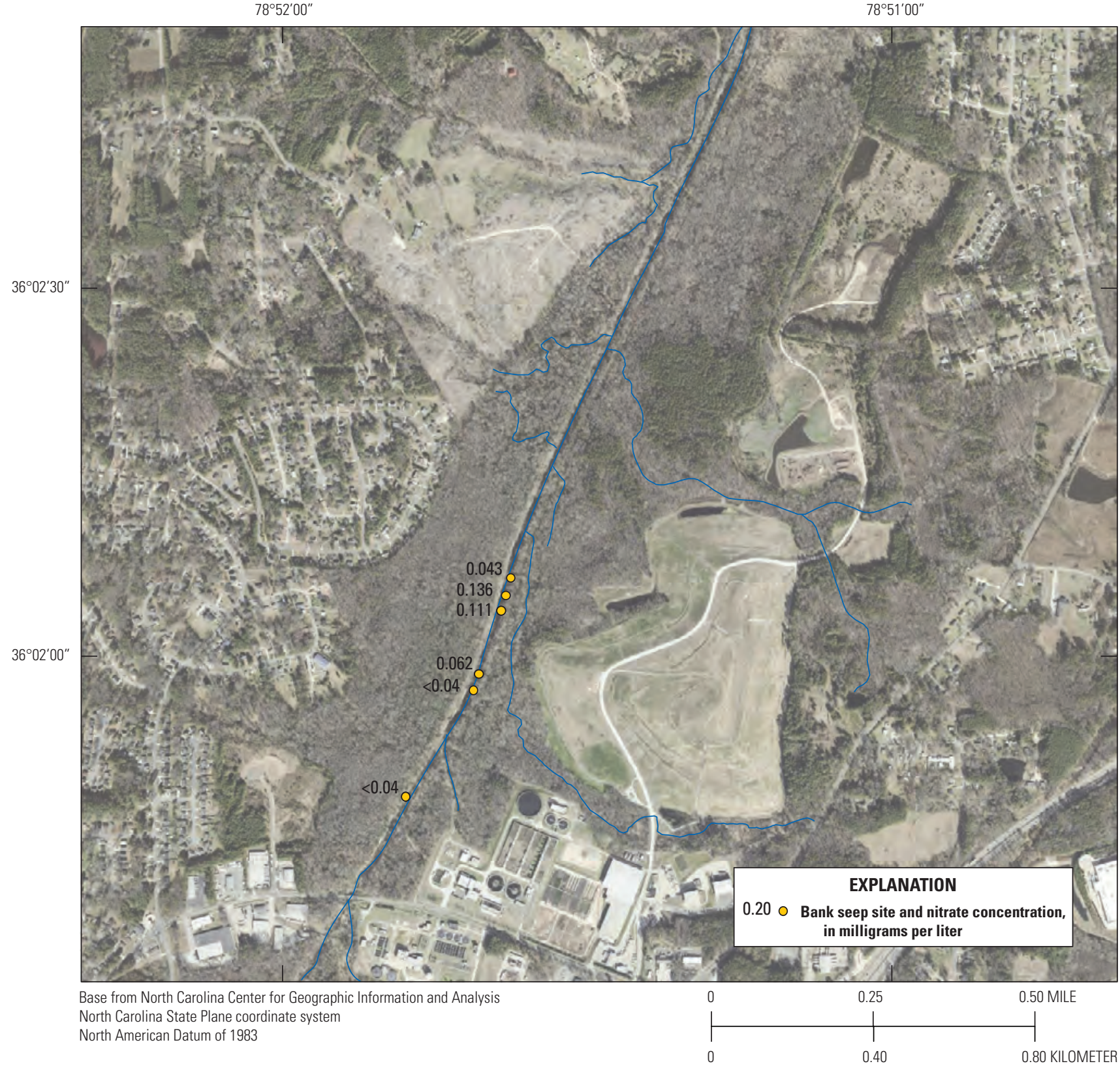

Figure 15. Map showing nitrate concentrations at bank seep sites sampled in July 2017 in the Ellerbe Creek study area in Durham, North Carolina. 


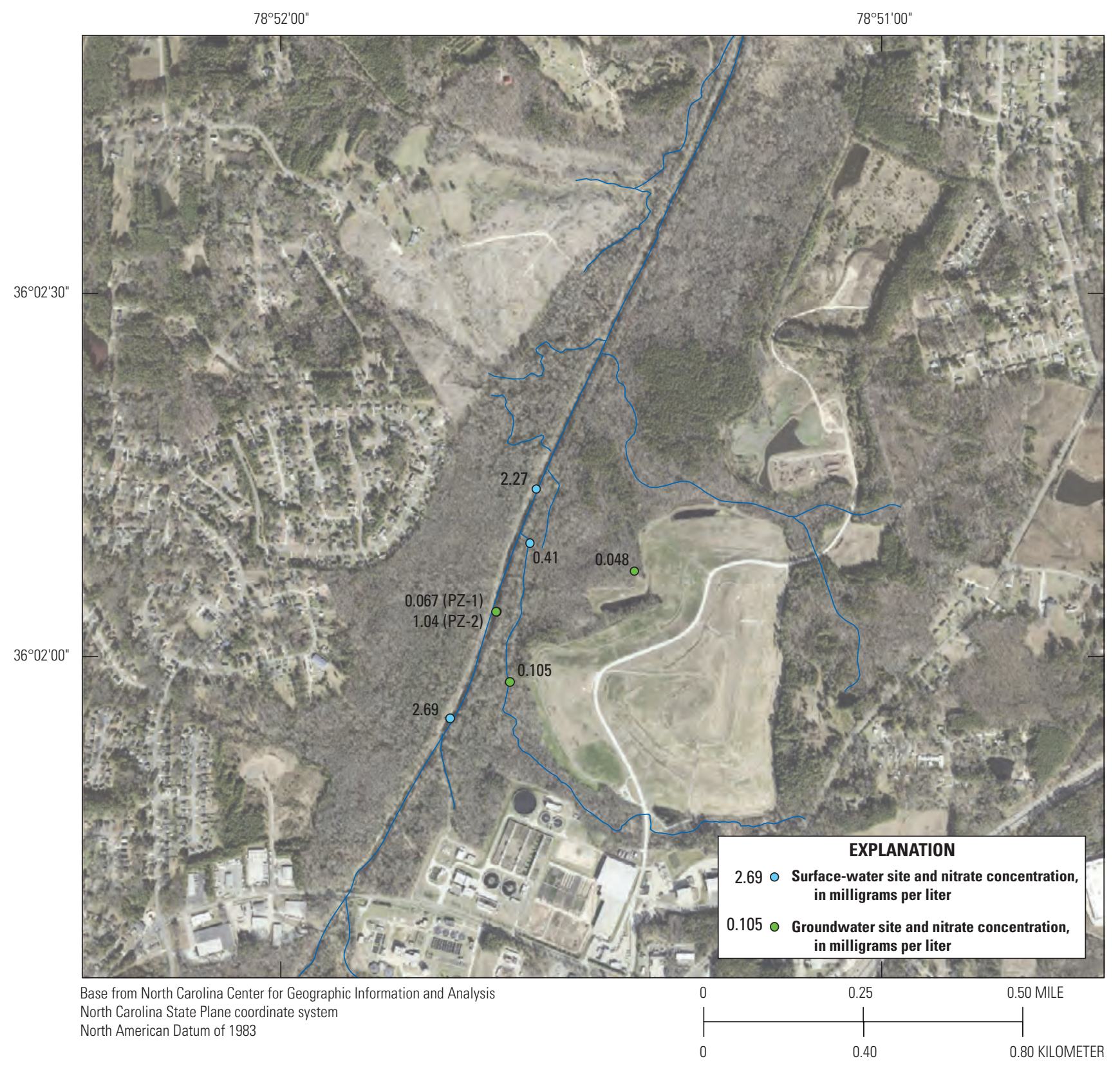

Figure 16. Map showing nitrate concentrations at surface-water and groundwater sites sampled in March 2018 in the Ellerbe Creek study area in Durham, North Carolina. PZ, piezometer. 


\section{Summary and Conclusions}

An assessment of groundwater and surface-water interactions along Ellerbe Creek in Durham, North Carolina, was conducted from July 2016 to March 2018 using a multimethod approach to understand if groundwater discharge is a source of nitrate to the stream. A streamflow gain-andloss survey showed that Ellerbe Creek has both gaining and losing reaches within the study area. Verifiable streamflow gain exists in reaches with surface-water inflows, such as from the North Durham Water Reclamation Facility (NDWRF) effluent outfall and small unnamed tributaries. Gains from groundwater generally were small — too small to quantitatively verify within the uncertainty limitations of the discharge measurement methods. Diabase dikes cut across the bedrock underlying the alluvial sediments in this area of Ellerbe Creek particularly within reach $\mathrm{F}$. The diabase dikes may act as an impermeable boundary to groundwater discharge, and preferential pathways along the weathered contact areas may divert groundwater along the dike.

Continuous water-level data collected within the stream, banks, and streambed show that Ellerbe Creek is largely a gaining stream within the study area. Hydraulic gradients were highest in the horizontal direction into the stream, with observed horizontal gradients twice the magnitude of those in the vertical direction. During storm events when streamflow is high, gradients temporarily reverse, and recharge through the streambed sediments and bank storage occurs for short durations. Groundwater levels likely are highest in late spring, which would lead to an increase in groundwater discharge through both the stream bank and streambed.

Hydrograph-separation methods yielded base-flow estimates ranging from 14.0 to 17.7 cubic feet per second $\left(\mathrm{ft}^{3} / \mathrm{s}\right)$, corresponding to contributions of up to 57 percent of streamflow in Ellerbe Creek in the study area. According to data provided by the NDWRF, average effluent discharge from the NDWRF is about $13 \mathrm{ft}^{3} / \mathrm{s}$, which accounts for more than 30 percent of the mean streamflow and nearly 80 percent of base flow in this reach of Ellerbe Creek. Groundwater discharge and tributary inflows along the stream account for the small remaining component of base flow. An estimated $3.7 \mathrm{ft}^{3} / \mathrm{s}$ of natural base flow was observed when effluent discharge was stopped for several hours during the study period. This base flow would account for about 9 percent of streamflow, which agrees with upper base-flow estimates calculated by the PART method.

Thermal imagery surveys of bank seeps along the stream show few persistent seeps during early spring and late summer. Bank-storage discharge likely accounts for much of the observed seepage from the stream banks; however, distinct temperature differences indicate that some bank seeps contain a measurable component of discharging groundwater. The fiber-optic distributed temperature sensing (FO-DTS) survey was able to resolve discharge from only one of the persistent seeps, likely because the area was sheltered from direct streamflow by a sandbar. These results indicate that the quantity of groundwater discharge along the reach is such a small contribution to the overall streamflow that it cannot be resolved by the FO-DTS system under these conditions. On the basis of base-flow estimations and flow calculated from water-level data, the groundwater component in Ellerbe Creek is less than 2 percent of the mean streamflow.

Nitrate concentrations were higher in surface water compared to the bank seeps and groundwater, with the highest concentration of 2.69 milligrams per liter $(\mathrm{mg} / \mathrm{L})$ in the reach just downstream from the NDWRF outfall. In comparison, samples collected at landfill groundwater monitoring wells contained nitrate concentrations less than or equal to $0.11 \mathrm{mg} / \mathrm{L}$ and low concentrations of dissolved oxygen, suggesting that conditions favoring denitrification exist at depth. Denitrification could help account for the relatively low concentrations of nitrate observed at the groundwater sites. Elevated nitrate concentrations within the bank seep and stream piezometer samples were highest after a storm event. These samples may reflect a mixture of stream-recharged bank storage and shallow groundwater.

Groundwater within the proximity of Ellerbe Creek does not have a strong influence on the hydrology and, as a consequence, the water-quality of the stream in the study reach. Groundwater flowing from the landfill towards the stream was not observed to exert influence on nitrogen concentrations in the study reach. The data collected during this study indicate that surface-water inflows, including the effluent discharge from the NDWRF, are of much greater importance to the streamflow and a greater nutrient source than groundwater discharge along the study reach of Ellerbe Creek. 


\section{References Cited}

Antolino, D.J., 2018, Groundwater-surface water interactions in Ellerbe Creek in Durham, North Carolina, 2016-2018: U.S. Geological Survey data release, https://doi.org/10.5066/P9YFET78.

Barlow, P.M., Cunningham, W.L., Zhai, T., and Gray, M., 2015, U.S. Geological Survey Groundwater Toolbox, a graphical and mapping interface for analysis of hydrologic data (version 1.0)-User guide for estimation of base flow, runoff, and groundwater recharge from streamflow data: U.S. Geological Survey Techniques and Methods, book 3, chap. B10, 27 p. [Also available at https://doi.org/10.3133/tm3B10.]

Bonn, B.A., 2008, Using the U.S. Geological Survey National Water Quality Laboratory LT-MDL to evaluate and analyze data: U.S. Geological Survey Open-File Report 2008-1227, 73 p. [Also available at https://doi.org/10.3133/ofr20081227.]

Briggs, M.A., Lautz, L.K., and McKenzie, J.M., 2012, A comparison of fibre-optic distributed temperature sensing to traditional methods of evaluating groundwater inflow to streams: Hydrological Processes, vol. 26, no. 9, p. $1277-$ 1290. [Also available at https://doi.org/10.1002/hyp.8200.]

Brown, P.M., and Parker, J.M., III, comps., 1985, Geologic map of North Carolina: North Carolina Department of Natural Resources and Community Development map, 1 sheet, scale 1:500,000.

Chapman, M.J., Bolich, R.E., and Huffman, B.A., 2005, Hydrogeologic setting, ground-water flow, and groundwater quality at the Lake Wheeler Road research station, 2001-03, North Carolina Piedmont and Blue Ridge Mountains Resource Evaluation Program: U.S. Geological Survey Scientific Investigations Report 2005-5166, 85 p. [Also available at https://doi.org/10.3133/sir20055166.]

Chapman, M.J., Cravotta, C.A., III, Szabo, Z., and Lindsay, B.D., 2013, Naturally occurring contaminants in the Piedmont and Blue Ridge crystalline-rock aquifers and Piedmont early Mesozoic basin siliciclastic-rock aquifers, Eastern United States, 1994-2008: U.S. Geological Survey Scientific Investigations Report 2013-5072, 74 p. [Also available at https://doi.org/10.3133/sir20135072.]

Cunningham, W.L., and Schalk, C.W., comps., 2011, Groundwater technical procedures of the U.S. Geological Survey: U.S. Geological Survey Techniques and Methods, book 1, chap. A1, 151 p., accessed October 16, 2014, at https://doi.org/10.3133/tm1A1.
Deitchman, R.S., and Loheide, S.P., II, 2009, Groundbased thermal imaging of groundwater flow processes at the seepage face: Geophysical Research Letters, v. 36, no. 14, L14401, 6 p. [Also available at https://doi.org/10.1029/2009GL038103.]

Dubrovsky, N.M., Burow, K.R., Clark, G.M., Gronberg, J.M., Hamilton, P.A., Hitt, K.J., Mueller, D.K., Munn, M.D., Nolan, B.T., Puckett, L.J., Rupert, M.G., Short, T.M., Spahr, N.E., Sprague, L.A., and Wilber, W.G., 2010, The quality of our Nation's waters-Nutrients in the Nation's streams and groundwater, 1992-2004: U.S. Geological Survey Circular 1350, 174 p. [Also available at https://doi.org/10.3133/cir1350.]

Fishman, M.J., ed., 1993, Methods of analysis by the U.S. Geological Survey National Water Quality Laboratory-Determination of inorganic and organic constituents in water and fluvial sediments: U.S. Geological Survey Open-File Report 93-125, 217 p. [Also available at https://doi.org/10.3133/ofr93125.]

Hallberg, G.R., and Keeney, D.R., 1993, Nitrate, chap. 12 of Alley, W.M., ed., Regional ground-water quality: New York, Van Nostrand Reinhold, p. 297-322.

Hanna, H.D., and Bradley, P.J., comps., 2016, Geologic map of Durham County, North Carolina: North Carolina Geological Survey Open File Report 2016-23, 1 sheet, scale 1:50,000.

Harden, S.L., Cuffney, T.F., Terziotti, S., and Kolb, K.R., 2013, Relation of watershed setting and stream nutrient yields at selected sites in central and eastern North Carolina, 1997-2008: U.S. Geological Survey Scientific Investigations Report 2013-5007, 47 p., 4 app. [Also available at https://doi.org/10.3133/sir20135007.]

Homer, C., Dewitz, J., Yang, L., Jin, S., Danielson, P., Xian, G., Coulston, J., Herold, N., Wickham, J., and Megown, K., 2015, Completion of the 2011 National Land Cover Database for the conterminous United States-Representing a decade of land cover change information: Photogrammetric Engineering and Remote Sensing, v. 81, no. 5, p. 345-354.

Institute of Hydrology, 1980a, Low flow studies-Report no. 1, research report: Wallingford, United Kingdom, Institute of Hydrology, $42 \mathrm{p}$.

Institute of Hydrology, 1980b, Low flow studies-Report no. 3, catchment characteristic estimation manual: Wallingford, United Kingdom, Institute of Hydrology, 27 p. 
Lambert, R.B., Opsahl, S.P., and Musgrove, M., 2017, Water quality, sources of nitrate, and chemical loadings in the Geronimo Creek and Plum Creek watersheds, south-central Texas, April 2015-March 2016: U.S. Geological Survey Scientific Investigations Report 2017-5121, 49 p. [Also available at https://doi.org/10.3133/sir20175121.]

Lauer, F., Frede, H.-G., and Breuer, L., 2013, Uncertainty assessment of quantifying spatially concentrated groundwater discharge to small streams by distributed temperature sensing: Water Resources Research, v. 49, no. 1, p. 400-407. [Also available at https://doi.org/10.1029/2012WR012537.]

McSwain, K.B., Bolich, R.E., Chapman, M.J., and Huffman, B.A., 2009, Water-resources data and hydrogeologic setting at the Raleigh hydrogeologic research station, Wake County, North Carolina, 2005-2007: U.S. Geological Survey OpenFile Report 2008-1377, 48 p. [Also available at https://pubs.er.usgs.gov/publication/ofr20081377.]

McSwain, K.B., Young, M.B., and Giorgino, M.L., 2014, Using stable isotopes of nitrogen and oxygen to identify sources of nitrate in three creeks, Durham County, North Carolina, 2011-12: U.S. Geological Survey Scientific Investigations Report 2014-5171, 22 p. [Also available at https://doi.org/10.3133/sir20145171.]

Messier, K.P., Kane, E., Bolich, R., and Serre, M.L., 2014, Nitrate variability in groundwater of North Carolina using monitoring and private well data models: Environmental Science \& Technology, v. 48, no. 18, p. 10804-10812. [Also available at https://doi.org/10.1021/es502725f.]

Mueller, D.K., Schertz, T.L., Martin, J.D., and Sandstrom, M.W., 2015, Design, analysis, and interpretation of field quality-control data for watersampling projects: U.S. Geological Survey Techniques and Methods, book 4, chap. C4, 54 p. [Also available at https://doi.org/10.3133/tm4C4.]

Mueller, D.S., Wagner, C.R., Rehmel, M.S., Oberg, K.A., and Rainville, F., 2013, Measuring discharge with acoustic Doppler current profilers from a moving boat (ver. 2.0, December 2013): U.S. Geological Survey Techniques and Methods, book 3, chap. A22, 95 p., accessed June 15, 2017, at https://doi.org/10.3133/tm3A22.

National Oceanic and Atmospheric Administration, 2015, 2015 NCFMP lidar-Statewide North Carolina (phase 3): Charleston, S.C., National Oceanic and Atmospheric Administration dataset, accessed June 4, 2018, at https://coast.noaa.gov/dataviewer.
North Carolina Department of Environment and Natural Resources, 2003, Ellerbe Creek local watershed plan: Raleigh, N.C., North Carolina Department of Environment and Natural Resources, 133 p., accessed July 17, 2018, at http://portal.ncdenr.org/web/eep/rbrps/neuse.

North Carolina Department of Environment and Natural Resources, 2010, NC 2010 integrated report categories 4 and 5 impaired waters: Raleigh, N.C., North Carolina Department of Environment and Natural Resources, 145 p.

North Carolina Department of Environmental Quality, Division of Water Resources, 2016, 2016 status report—Falls Lake nutrient strategy: Raleigh, N.C., North Carolina Department of Environmental Quality, Division of Water Resources, 65 p., accessed June 4, 2018, at https://ncdenr.s3.amazonaws.com/s3fs-public/ Environmental\%20Management\%20Commission/EMC\%20 Meetings/2016/March2016/Attachments/AttachA_ InfoItem16-02Huisman10Mar16.pdf.

Pandey, P., Gleeson, T., and Baraer, M., 2013, Toward quantifying discrete groundwater discharge from frozen seepage faces using thermal infrared images: Geophysical Research Letters, v. 40, no. 1, p. 123-127. [Also available at https://doi.org/10.1029/2012GL054315.]

Piper, A.M., 1953, A graphic procedure in the geochemical interpretation of water analyses: U.S. Geological Survey Ground-Water Note 12, 14 p.

Rutledge, A.T., 1998, Computer programs for describing the recession of ground-water discharge and for estimating mean ground-water recharge and discharge from streamflow records-Update: U.S. Geological Survey Water-Resources Investigations Report 98-4148, 43 p., accessed June 4, 2018, at https://doi.org/10.3133/wri984148.

Selker, J.S., Thévenaz, L., Huwald, H., Mallet, A., Luxumberg, W., van de Giesen, N., Stejskal, M., Zeman, J., Westhoff, M., and Parlange, M.B., 2006, Distributed fiberoptic temperature sensing for hydrologic systems: Water Resources Research, v. 42, no. 12, 8 p., accessed June 4, 2018, at https://doi.org/10.1029/2006WR005326.

Sincich, T., 1993, Statistics by example: Upper Saddle River, N.J., Prentice Hall, 1,024 p.

Stonestrom, D.A., and Constantz, J., eds., 2003, Heat as a tool for studying the movement of ground water near streams: U.S. Geological Survey Circular 1260, 96 p. [Also available at https://doi.org/10.3133/cir1260.]

Turnipseed, D.P., and Sauer, V.B., 2010, Discharge measurements at gaging stations: U.S. Geological Survey Techniques and Methods, book 3, chap. A8, 87 p. [Also available at https://doi.org/10.3133/tm3A8.] 
U.S. Geological Survey, 1992, Review process for samples analyzed at the National Water Quality Laboratory (NWQL): National Water Quality Laboratory Technical Memorandum 93-02, 5 p., accessed November 2013 at http://nwql.usgs.gov/tech_memos/nwql.93-02.html.

U.S. Geological Survey, 2006, Collection of water samples (ver. 2.0, September 2006): U.S. Geological Survey Techniques of Water-Resources Investigations, book 9, chap. A4, 166 p., accessed June 4, 2018, at https://doi.org/10.3133/twri09A4.

U.S. Geological Survey, 2018, USGS water data for the Nation: U.S. Geological Survey National Water Information System database, accessed June 4, 2018, at https://doi.org/10.5066/F7P55KJN.
Wahl, K.L., and Wahl, T.L., 1995, Determining the flow of Comal Springs at New Braunfels, Texas, in Proceedings of Texas Water 95-August 16-17, 1995, San Antonio, Texas: American Society of Civil Engineers, p. 77-86.

Weaver, J.C., and McSwain, K.B., 2013, Determination of flow losses in the Cape Fear River between B. Everett Jordan Lake and Lillington, North Carolina, 2008-2010: U.S. Geological Survey Scientific Investigations Report 2012-5226, 76 p. [Also available at https://doi.org/10.3133/sir20125226.]

Young, K.B., 1950, A comparative study of mean-section and mid-section methods for computation of discharge measurements: U.S. Geological Survey Open-File Report 53-277, 52 p., accessed April 24, 2015, at https://doi.org/10.3133/ofr53277. 
For more information concerning the research in this report, contact Director, South Atlantic Water Science Center

U.S. Geological Survey

720 Gracern Road

Stephenson Center, Suite 129

Columbia, SC 29210

Publishing support provided by the U.S. Geological Survey Science Publishing Network, Reston and Sacramento

Publishing Service Centers 
